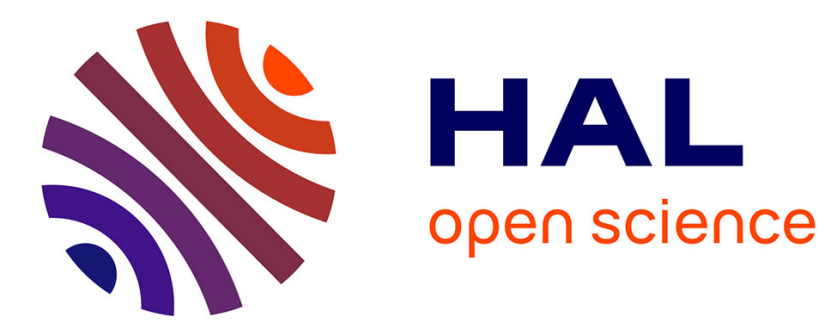

\title{
Evidence on new technologies and wage inequality in France
}

Eva Moreno-Galbis, François-Charles Wolff

\section{To cite this version:}

Eva Moreno-Galbis, François-Charles Wolff. Evidence on new technologies and wage inequality in France. Applied Economics, 2009, 43 (7), pp.855. 10.1080/00036840802600004 . hal-00582231

\section{HAL Id: hal-00582231 \\ https://hal.science/hal-00582231}

Submitted on 1 Apr 2011

HAL is a multi-disciplinary open access archive for the deposit and dissemination of scientific research documents, whether they are published or not. The documents may come from teaching and research institutions in France or abroad, or from public or private research centers.
L'archive ouverte pluridisciplinaire HAL, est destinée au dépôt et à la diffusion de documents scientifiques de niveau recherche, publiés ou non, émanant des établissements d'enseignement et de recherche français ou étrangers, des laboratoires publics ou privés. 


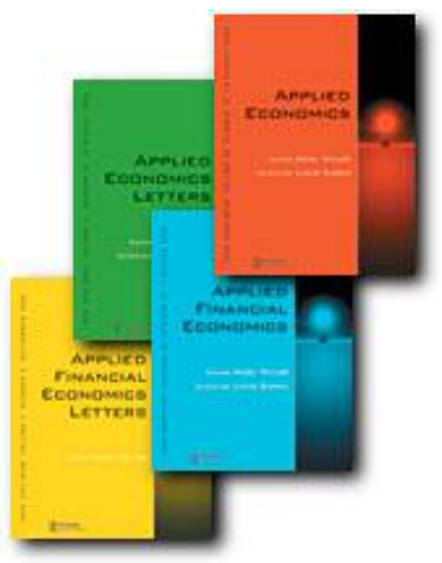

Evidence on new technologies and wage inequality in France

\begin{tabular}{|c|c|}
\hline Journal: & Applied Economics \\
\hline Manuscript ID: & APE-07-0176.R1 \\
\hline Journal Selection: & Applied Economics \\
\hline $\begin{array}{r}\text { Date Submitted by the } \\
\text { Author: }\end{array}$ & 04-Sep-2008 \\
\hline Complete List of Authors: & $\begin{array}{l}\text { Moreno-Galbis, Eva; Université du Maine } \\
\text { Wolff, Francois-Charles; University of Nantes }\end{array}$ \\
\hline JEL Code: & $\begin{array}{l}\text { O33 - Technological Change: Choices and Consequences|Diffusion } \\
\text { Processes < O3 - Technological Change|Research and Development } \\
<\text { O - Economic Development, Technological Change, and Growth, } \\
\text { J31 - Wage Level, Structure; Differentials by Skill, Occupation, etc. } \\
<\text { J3 - Wages, Compensation, and Labor Costs < J - Labor and } \\
\text { Demographic Economics }\end{array}$ \\
\hline Keywords: & $\begin{array}{l}\text { Technological wage gap, information and communication } \\
\text { technologies, quantile regressions }\end{array}$ \\
\hline
\end{tabular}

\section{\scholarONE" \\ Manuscript Central}




\author{
Eva Moreno-Galbis *
}

\author{
François-Charles Wolff **
}

\title{
Evidence on new technologies and wage inequality in France ${ }^{\#}$
}

First revision, Applied Economics

September 2008

\begin{abstract}
Using individual data from the French Labor Force Survey and the Complementary Survey on Working Conditions for 1998, we analyze earnings inequalities along the wage distribution between workers using novel technologies (ICT) at their job and those not using them. We estimate quantile regressions with technological dummies and carry out a decomposition analysis, both at the aggregate level and by occupations. At the aggregate level, most of the wage gap between both populations is explained by the divergence in their labor characteristics. In jobs where ICT are not very diffused, the technological premium is larger than in jobs characterized by a large presence of novel technologies. Whereas in the former type of jobs, the technological premium is mainly justified by a divergence in the labor market characteristics between ICT users and non users, in positions characterized by a wide presence of novel technologies the technological premium responds rather to a divergence in the returns to identical characteristics.
\end{abstract}

Keywords: Technological wage gap, information and communication technologies, quantile regressions

JEL Classification: J31, J71, O33

\footnotetext{
\# We would like to thank seminar participants at the Université du Maine, the TEMA seminar of Paris I and the EALE Conference 2006. We are especially indebted to two anonymous referees, David Margolis, Jean-Marc Robin and Catherine Sofer for their very useful comments and suggestions. Any remaining errors are ours.

* Corresponding author. Université du Maine, Avenue O. Messiaen, 72085 Le Mans Cedex 9, France; and CEPREMAP, Paris, France.

Email: eva.moreno-galbis@univ-lemans.fr

** LEN, Université de Nantes, BP 52231 Chemin de la Censive du Tertre, 44322 Nantes Cedex 3, France; CNAV and INED, Paris, France.

Email: wolff@sc-eco.univ-nantes.fr Homepage: http://www.sc-eco.univ-nantes.fr/ fcwolff
} 


\section{Introduction}

The introduction of information and communication technologies (ICT hereafter) over the past decades has fostered an upturn in the returns to human capital, and more particularly in the rewards to workers using novel technologies at their job. Traditionally, most of the existing literature on the subject had focused on the effects of ICT on average wage inequalities between skilled and unskilled workers or between workers using and not using novel technologies (Davis and Haltiwanger, 1991, Krueger, 1993, Autor et alii 1998, Krusell et alii, 2000, Lee and Kim, 2004). However, more recently, some studies on the U.S. and the U.K. economies have analyzed inequalities along the wage distribution (Autor et alii, 2006, Lemieux, 2006, Goos and Manning, 2003). Our paper belongs to this last stream of literature. Drawing on French data, we seek to provide a complete picture on earnings inequalities between ICT users and not users along the wage distribution and target the problem through an analysis by occupations.

Many papers studying the evolution of the skill-premium over the past decades point towards biased technological progress and the complementary relationship between new technologies and skilled labor as the main factor responsible for the increasing trend observed in high-skilled relative wages. Krueger (1993) claims that workers using computers at their job earn $10-15 \%$ higher wages than non-users. Furthermore, the tremendous expansion of computers during the $80 \mathrm{~s}$ accounts for one-third to one-half of the rise in the returns to education. Lee and Kim (2004) confirm Krueger's findings for the nineties. They conclude that the computer premium has been persistent during this decade, while the Internet premium decreased sharply between 1997 and 2001.

Autor et alii (1998) or Davis and Haltiwanger (1991) also underline the role of skillbiased technological progress as the driving force of wage inequalities in the U.S. since the second half of the twentieth century. Using U.S. data, Krusell et alii (2000) find that during the 90s, the development of better and cheaper capital equipment being more complementary with skilled labor drove down relative wages of unskilled workers. Concerning European countries, Caroli and Van Reenen (2001) estimate that the increase in earnings inequalities inside French and British firms between high-skilled and low-skilled workers is due to the introduction of skill-biased technological and organizational practices.

Studies on average wage inequalities agree on the fact that novel technologies increase the returns to education and the rewards to ICT users. However, as recently shown by the gender gap literature (Albrecht et alii, 2003, Jellal et alii, 2008), a great amount of information is lost when focusing on average inequalities. A much more complete picture on wage 
inequalities between two populations is achieved when considering inequalities along the whole distribution (while controlling for labor market characteristics). Given that occupations are spread along the wage distribution and that ICT are not equally diffused among occupations, we wonder whether the rewards associated to the use of novel technologies differ depending on the considered occupation.

There starts to be nowadays a non negligible amount of papers interested in aggregate wage inequalities along the wage distribution. This literature refers to the role of novel technologies in promoting the upturn of wage inequalities along the distribution between the $90^{\text {th }}$ and $50^{\text {th }}$ percentiles and between the $50^{\text {th }}$ and $10^{\text {th }}$ percentiles, but it does not deal at all with earning differentials exclusively explained by the use of novel technologies. Autor et alii (2006) and Goos and Manning (2003) conclude that in the U.S. and the U.K., novel technologies are promoting a polarization of the labor market. Computer capital is progressively replacing medium skilled workers in routine tasks at the middle of the wage distribution, while complementing labor input in non routine positions, particularly in non routine cognitive positions at the top of the wage distribution. Productivity and thus wages at the upper tail of the wage distribution have largely increase with ICT adoption.

In contrast, Autor et alii (2006) predict ambiguous effects on wages of manual non routine jobs, since novel technologies are less complementary with respect to these positions and medium skilled workers displaced from routine jobs are reemployed in manual non routine tasks. This leads to less important increase in inequalities between the $50^{\text {th }}$ and the $10^{\text {th }}$ percentiles. Finally, Autor et alii (2005) find that male $90^{\text {th }}-10^{\text {th }}$ residual wage inequality rose sharply between 1973 and 1988, and then contracted by about 15 to $30 \%$ of its original rise between 1988 and 2003 (holding composition constant). Changing residual prices are primarily responsible for the rise (1973-1988) and then contraction (1988-2003) of residual inequality. Compositional effects are found to be modest relative to price effects ${ }^{1}$.

In this paper, we extend this literature where the role of ICT as a factor responsible for the rise in aggregate wage inequalities (particularly in the upper tail of the distribution) is mentioned, but not explicitly treated. Our analysis uses individual data obtained from the French Labor Force Survey and the Complementary Survey on Working Conditions during the 90s. We first distinguish between workers using ICT (modern workers) and those not using them (traditional workers), and systematically consider three different definitions of

\footnotetext{
${ }^{1}$ Lemieux (2006) attributes to compositional effects the rise in the variance of unobserved skills observed in the U.S. over the past 30 years. Autor et alii (2005) findings can though be reconciled with Lemieux's findings if the study is focused on the actual net rise in estimated residual inequality from 1988 to 2003.
} 
modern/traditional workers to ensure the robustness of our results. We focus on earnings differentials between ICT users and non users along the conditional wage distribution so as to determine whether the use of a novel technology is better rewarded at the top or at the bottom of the conditional wage distribution.

A central concern is that comparing the earnings of ICT users and non users may lead to a selection problem. Using a novel technology is likely to result from the discretionary choice of a worker, this choice being based on potential wages, so that estimates of the returns to labor market characteristics of ICT users and non users may be biased. From an empirical perspective, a difficulty is to find suitable exclusion restrictions, i.e. variables which influence the use of ICT and not the level of wage. As the data at hand do not provide such convincing variables, we proceed in the following way to circumvent this difficulty.

We first analyze the technological premium along the conditional wage distribution for the whole population. We determine the share of the technological premium explained by the objective differences in the labor market characteristics and the share resulting rather from a divergence in the rewards to identical characteristics. Because the divergence in the labor market characteristics arises as the main factor responsible for the technological premium, we then discuss in more detail the potential bias stemming from selection issue and present additional evidence on the basis of a propensity score approach. Finally, we turn to a more detailed analysis by occupations. Based on the potential wage, we argue that people apply to a particular occupation, but once they get in, the use of a novel technology is more likely to be imposed by an external decision, i.e. the firm policy.

The remainder of this paper is organized as follows. Section 2 describes the data sources, the used variables, and it also provides a descriptive analysis of our sample. Section 3 implements a quantile regression analysis where we investigate differences in labor market characteristics between modern and traditional workforces. It also includes a discussion and results about the selection issue. The analysis of the technological gap by occupations is then presented in section 4. Finally, section 5 concludes.

\section{Data and descriptive statistics}

\subsection{The data sources}

We use the French Labor Force Survey and the Complementary Survey on Working Conditions for 1998. In the Labor Force Survey, a representative sample of 135000 individuals (belonging to 65000 households) being older than 15 years is annually interviewed and questioned on their personal and professional status. The survey contains 
information concerning the main activity of the individual during the survey week, seniority at a job, occupation, wage, size of the firm, age, marital status, number of children, education, nationality and so forth. Every year, a third of the sample is renewed implying that each individual is interviewed only 3 times. The rate of sampling is $1 / 300$.

The Complementary Survey on Working Conditions is conducted every seven years on a representative sample of 21000 employed workers of the outgoing sample of the Labor Force Survey. This survey covers four fields of interest: i) organization and timetable of working days, ii) workplace organization and job content, iii) working risks, and iv) degree of harmfulness of the job. We focus on the second field, where we dispose information concerning the use of new technologies by the workers. Because our paper seeks to analyze earnings inequalities between ICT users and non users, we eliminate from the sample all individuals working in the public sector, where wages are fixed by law and do not respond to productivity reasons ${ }^{2}$. Our remaining sample covers exactly 8794 individuals for $1998^{3}$.

We adopt the log of the monthly wage as our dependent variable. We classify every worker as modern or as traditional depending on whether she uses or not novel technologies. The Complementary Survey on Working Conditions provides information on the following variables:

- COMPUTER1: The worker uses a computer connected to an internal or external network.

- COMPUTER2: The worker uses a computer not connected to any network.

- TERMINAL: The worker uses a console.

- INTERNET: The worker uses internet with a professional objective.

- ROBOT: The worker uses robots or other machine tools being able to move autonomously.

- OTHERS: The worker uses other informatics material.

- ORDERINT: The worker receives internal orders from a computer.

- ORDEREXT: The worker receives external orders from a computer.

In order to assess the robustness of our results, we will systematically implement the analysis considering three indicator variables embedded the one in the other. The variable

\footnotetext{
${ }^{2}$ We choose to exclude all individuals who are not full-time workers so as to avoid preference issues problems, and also because for partial time workers it is not always a choice to be at part time. We also eliminate all individuals with missing observations.

${ }^{3}$ A shortcoming of these data is that they concern individuals. Not working with plant data limits the possibility of our econometric study to capture the positive productivity spillovers that someone not using ICT, but being employed in a plant where everybody uses them, may receive.
} 
MODERN1 adopts the unitary value when the individual uses at least one of the novel technologies. In 1998, 53\% of the individuals were in this situation. The indicator MODERN2 is equal to one when the individual uses two or more novel technologies. Finally, MODERN3 adopts the unitary value when the individual uses at least 3 novel technologies. These three indicators, MODERN1, MODERN2 and MODERN3, increase progressively the tightness of the definition of modern workers, providing various measures concerning the intensity of use of novel technologies.

\subsection{The sample characteristics}

The existence of wage differentials between modern and traditional workers is clearly displayed in Figure 1. On average, an ICT user earns $28.7 \%$ more than a non-user. Besides, the technological premium increases smoothly along the distribution, even though it is slightly accelerating at the top of it. Such a pattern is quite different from the glass ceiling phenomenon traditionally observed when focusing on the gender gap. In the first decile, we find that modern workers earn $14.3 \%$ more. In the first quartile, they earn $21.2 \%$ more, in the second quartile this difference raises to $28.7 \%$. It attains $36.7 \%$ in the third quartile and $53.2 \%$ in the ninth decile of the distribution. The wage gap between both types of workforces reaches therefore a maximum at the top of the distribution.

\section{Insert Figure 1 here}

These results are merely descriptive. As such, they have to be interpreted with caution since we are not controlling for the fact that in same deciles of two distinct populations, we find individuals with very different characteristics that influence their wages (for example labor market characteristics in terms of education, occupation, etc). The observed gap does not exclusively respond therefore to the use of novel technologies, but also to other differing characteristics that we will have to control for in the econometric analysis.

Descriptive statistics summarized in Panel A of Table 1 indicate that on average, ICT users have the same age as non users. However, they have more seniority at the job. In terms of years of schooling, the share of highly-educated workers (baccalaureate, undergraduate, graduate and postgraduate diploma) is also more important inside the modern group of workers. Finally, people using novel technologies are more likely to work in large firms of more than a hundred employees than traditional workers.

A more detailed analysis by type of technology (panels B and C of Table 1) reveals that people using internet or a computer connected to a network are younger and have less seniority than non users. Moreover, people receiving internal or external orders through a computer, using internet, an informatics terminal, a computer or other informatics material 
have a higher educational level, are more likely to be managers, technicians or intermediate professionals and work more often in very large firms (more than five hundreds employees).

\section{Insert Table 1 here}

At the same time, differences between being a user or not of a novel technology may lead to a selection problem. Working at a more detailed level allows to greatly reduce the bias entailed by selectivity issue, at least under the assumption that using ICT at work is a decision made by the firm that does not depend on unobservable characteristics of the worker. Specifically, we distinguish six types of occupations in the French data: managers, intermediate professions, technicians, employees, skilled production workers and unskilled production workers. Inside each occupation, we distinguish between the group of workers using ICT (modern) and those not using them (traditional). Again, we consider three definitions of modernity, i.e. MODERN1, MODERN2 and MODERN3.

As shown in Figure 2, novel technologies are not equally diffused among all occupations. Actually, around $62 \%$ of managers use three or more technologies at their job. For intermediate professions or technicians, these percentages are reduced respectively to $36 \%$ and $46 \%$. Only $28 \%$ of employees and less than $10 \%$ of production workers (skilled or unskilled) employs more than three ICT at their job. When considering larger definitions of modern workers (either MODERN1 or MODERN2), this ranking of occupations concerning the use of novel technologies is repeated. The most intensive use of ICT corresponds thus to managers, followed by intermediate professions, technicians, and to a lesser extent by employees and production workers.

\section{Insert Figure 2}

Among highly paid positions (managers, intermediate professions and technicians), the use of a computer connected to a network and the reception of internal orders through a computer are strongly related. Around two thirds of these highly paid workers employing a computer connected to a network receive internal orders through it. Results concerning MODERN1 and MODERN2 are very similar. For middle and low paid positions, COMPUTER1 and ORDERINT continue to be the two ICT presenting the strongest correlation, but only $28 \%$ of the middle paid and $9 \%$ of the low paid uses a connected computer at their job ${ }^{4}$. Middle and low paid people classified as modern under MODERN1 are more different from those classified as modern under MODERN2, than when working with highly paid positions where MODERN1 and MODERN2 are very similar.

\footnotetext{
${ }^{4}$ Around $59 \%$ of the formers and $51 \%$ of low paid workers using a connected computer at their job receives also internal orders through a computer.
} 
This unequal use of novel technologies among occupations is expected to influence the wage gap observed between modern and traditional workers within each type of occupation. In Figure 3, we find that in occupations where ICT are the least diffused, i.e. for employees, skilled and unskilled production workers, earnings differentials between ICT users and non users are the most important. In contrast, in occupations characterized by a wide usage of novel technologies, the earning gap is more reduced. The use of ICT seems therefore to be better rewarded in positions where its presence is scarce.

Also, Figure 3 suggests that the definition of the modern indicator may have an impact on the magnitude of the technological premium, however this effect is not homogeneous among categories. Whereas in occupations where novel technologies are not largely diffused a tighter definition of modern worker (MODERN3) is generally associated to a larger wage gap, this result does not hold when considering managers, intermediate professions and technicians.

\section{Insert Figure 3}

Again, these results do not control for differences in labor market characteristics between traditional and modern workforces within occupations. This is certainly less problematic in a context where wage inequalities are analyzed by occupations. People apply to a particular job based on potential wage and thus ICT content, knowing that the labor market characteristics they have match well to the specific position they apply. Divergences in the labor market characteristics of modern and traditional workers within a given occupation are likely to be smaller than when we compare both workforces at the aggregate level, an expectation which is clearly supported by the results reported in Table 2.

\section{Insert Table 2}

Among managers and technicians, differences in educational levels between traditional and modern workforces arise essentially at the undergraduate and postgraduate levels 5 . Two of the most important differences between both workforces inside occupations are age and nationality. ICT-users are systematically younger than non-users, the difference being particularly large when considering high-paid occupations. Furthermore, modern workers are more likely to have French nationality than traditional ones when we focus on low-paid occupations. Finally, modern workers are more likely to be employed in larger firms than traditional ones. These findings hold for the three indicators MODERN1, MODERN2 and MODERN3. Whatsoever, to better control for differences in individual characteristics, we

\footnotetext{
${ }^{5}$ For the rest of the occupations, there are not very significant differences in terms of diploma between ICT-users and non-users, apart from the baccalaureate and undergraduate diploma in the employees' case.
} 
now turn to an econometric analysis where we estimate the magnitude of the technological premium using quantile regressions both at the aggregate at the level and by occupations.

\section{Quantile regressions on the aggregate technological premium}

\subsection{Pooled quantile regressions with technological dummy}

Using the whole sample, we first investigate the extent to which the gap in the log wage distribution between modern and traditional workforces can be attributed to differences in the labor market characteristics of these workers, such as age, years of schooling, seniority or nationality. The effects of the covariates on the location, scale and shape of the conditional wage distribution can be easily estimated using a quantile regression framework ${ }^{6}$. This is a major advantage compared to the least square model, which leads only the effects on the location, i.e. the conditional mean of the distribution.

Since the quantile regression framework allows characteristics to have different returns at different quantiles, at each point of the distribution it can control more fully for differences between wages paid to ICT users and non users that are attributable to divergent labor market characteristics. More precisely, this technique estimates the $\theta^{\text {th }}$ quantile of a variable conditional on covariates. The $\theta^{\text {th }}$ quantile of a random variable $y$ (which is the monthly wage in our case) conditional on $x$ is the value of $q(\theta)$ such that $\operatorname{Pr}\left(y \leq q_{\theta} / x\right)=\theta$ for $\theta \in(0,1)$. The quantile regression model assumes that $q(\theta)$ is linear in $x$, that is $q_{\theta}=x \beta(\theta)$.

We carry out a series of quantile regressions on a pooled 1998 dataset, resulting from combining the dataset of modern workers with the dataset of traditional workers. Importantly, these pooled quantile regressions impose the restriction that the returns to included labor market characteristics are the same for ICT users and non users. More precisely, let $w_{i}$ be the log wage of individual $i$ and $x_{i}$ a vector of explanatory variables excluding the technological dummy (either MODERN1, MODERN2 or MODERN3). The model we estimate is:

$$
q_{\theta}\left(w_{i} \mid x_{i}\right)=x_{i}^{\prime} \beta(\theta)+\operatorname{MODERN}_{i} \gamma(\theta)
$$

where $q_{\theta}\left(w_{i} \mid x_{i}\right)$ is the $\theta^{\text {th }}$ conditional quantile of $w_{i}$. The set of coefficients $\beta(\theta)$ provides the estimated rate of return to the covariates at the $\theta^{\text {th }}$ quantile of the log wage distribution. We introduce as covariates in the quantile regression a gender dummy, the age of the worker,

\footnotetext{
${ }^{6}$ See Koenker and Bassett (1978) for a detailed description of the quantile regressions.
} 
a quadratic profile of the age, seniority, a quadratic profile of seniority, years of schooling, occupation $^{7}$, nationality of the worker, the firm's size and a set of 35 sectoral dummies. The estimated technological dummy coefficient $\gamma(\theta)$, respectively for MODERN1, MODERN2 and MODERN3, indicates the extent to which the technological wage gap remains unexplained at the various quantiles when we control for differences in the observed characteristics of modern and traditional workers.

In Table 3, we summarize the estimated technological dummy coefficients and the returns to the considered labor market characteristics at the 10th, 25th, 50th, 75th and 90th percentiles using the pooled 1998 data and the MODERN1 indicator. We find that the technological premium remains fairly stable and small along the conditional wage distribution, at around $7 \%^{8}$. It is equal to $7.7 \%$ at the first decile, $6.6 \%$ at the first quartile, $7.1 \%$ at the median, $6.4 \%$ at the third quartile and $7.8 \%$ at the ninth decile. When controlling for differences in labor market characteristics and when assuming that modern and traditional workers are equally rewarded for identical characteristics, wage differentials between ICTusers and non-users are greatly reduced and the upward trend displayed by the observed gap disappears.

Two additional comments are in order. First, this finding is not really sensitive to the definition of the technological variable. In Figure 4, we compare the magnitude of the estimated technological premium with the three indicators. Interestingly, we evidence very similar profiles for MODERN1, MODERN2, MODERN3, meaning that the premium at the aggregate level is mainly due to the use of new technologies and not to its intensity. The premium is around 1 or 2 points of percentage lower with a more intensive use of ICT, except at the top of the distribution ${ }^{9}$.

\section{Insert Figure 4}

Second, there are some strong differences in the earnings pattern depending on occupation, as shown in Table 3. For instance, earnings of managers are on average about $71.4 \%$ higher than those of unskilled manual workers (reference group), and the gap is still more than $30 \%$ for intermediates and technicians. As the diffusion of ICT also varies with the occupation, this suggests that this aggregate analysis may lead to an overestimated impact of the use of new technologies on earnings.

\footnotetext{
${ }^{7}$ Evidently, occupations are differentiated by their ICT content. Therefore, not controlling for them in the regression would leave a lot of noise and would lead to an overestimation of the impact of ICT. We include occupations in the aggregate analysis and implement afterwards a detailed study by occupations.

${ }^{8}$ At the mean of the sample (OLS regression), the technological premium amounts to $7.3 \%$.
} 


\subsection{The specific returns of ICT and quantile regression decomposition}

A difficulty with the above findings is that they are based on a somewhat restrictive constraint, i.e. the equality in the returns to included labor market characteristics between modern and traditional workers. In order to test whether the rewards to individual characteristics are equal between the modern and the traditional workforces, we implement a quantile regression analysis distinguishing between the common effect affecting both types of workers, which is represented by means of the individual covariate variables, and the specific effect exclusively associated to ICT users. This last effect is captured through the introduction of interacted explicative variables resulting from multiplying the dummy MODERN by the corresponding covariate. If these interacted terms are jointly significant, we cannot accept the hypothesis of equality in the returns to labor market characteristics since there are significant specific effects linked to the use of ICT.

Specifically, to assess the joint significativeness of the different interacted terms, we rely on a F-test for each quantile regression. Our results reveal that the value of the joint F-test is always significant at the 1 percent level, implying that the hypothesis of equal returns to labor market characteristics has to be rejected ${ }^{10}$. This means that we cannot properly measure the technological gap from the pooled sample including both types of workers.

Because we are working with a linear model, we develop the well known OaxacaBlinder decomposition, which permits to decompose the estimated technological gap into one component that results from the difference in the labor market characteristics between ICT users and non users, and another component that is explained by the difference in the rewards to identical labor market characteristics (see Oaxaca and Ramson, 1994). As we are interested in the technological premium over the wage distribution, we implement such decomposition at each quantile of the wage distribution following the technique developed in Machado and Mata (2005).

Let $\beta^{t}$ and $\beta^{m}$ denote respectively the returns to individual characteristics $x^{t}$ and $x^{m}$ in the traditional and the modern group of workers. The decomposition of the technological wage gap can be expressed as follows:

$$
x^{m} \beta^{m}(\theta)-x^{t} \beta^{t}(\theta)=x^{m}\left[\beta^{m}(\theta)-\beta^{t}(\theta)\right]+\left[x^{m}-x^{t}\right] \beta^{t}(\theta)
$$

where $\left[x^{m}-x^{t}\right] \beta^{t}(\theta)$ stands for the part of the technological premium explained by differences in labor market characteristics between the high-tech and low-tech workforces.

\footnotetext{
${ }^{9}$ At the top of the distribution (i.e. the $90^{\text {th }}$ percentile), the premium is slightly higher with MODERN3 than with MODERN1, while there is no difference between MODERN1 and MODERN2.
} 
The term $x^{m}\left[\beta^{m}(\theta)-\beta^{t}(\theta)\right]$ corresponds to the fraction of the premium attributable to differences in the returns to these characteristics ${ }^{11}$.

When using the Machado-Mata approach, we generate a counterfactual density. We proceed in the following way to generate. First, we draw $n$ numbers at random from the interval $(0,1)$, say $\theta_{1}, \theta_{2}, \ldots, \theta_{n}$. Then, using the traditional group dataset, we estimate the quantile regression coefficient vectors $\beta^{t}\left(\theta_{i}\right)$ for $i=1, \ldots, n$. Finally, we make $n$ draws at random with replacement from the modern group dataset, denoted by $x_{i}^{m}$ for $i=1, \ldots, n$. The counterfactual density is generated as $x_{i}^{m} \beta^{t}\left(\theta_{i}\right)$ for $i=1, \ldots, n$, i.e. we have traditional workers with the labor market characteristics of modern ones, but paid as non ICT users.

Results of both the linear and quantile decompositions are in Table 4, with different definitions of modern worker. At the mean of the sample, with the MODERN1 indicator, we find that the estimated gap is equal to $33.7 \%$. The bulk of this gap stems from differences in characteristics between traditional and modern workers, which amount to $28.9 \%$. The component due to differences in the rewards of observable characteristics is much lower, around $4.7 \%$. Very similar conclusions are reached with the MODERN2 and MODERN3 indicators. In all cases, the technological premium is of a very similar order, about $35 \%$. Furthermore, it mainly results from differences in the characteristics between non-ICT users and ICT users.

\section{Insert Table 4 here}

When turning to the quantile decomposition, independently of the technological indicator, the divergence in the labor market characteristics arises as the main factor responsible for the earning differential between ICT users and non users. The only exception is for the $1^{\text {st }}$ decile with MODERN1, where the component due to differences in the returns to identical characteristics stands for one third of the total difference.

So, the estimated technological premium along the wage distribution seems to respond to differences in the workers' characteristics. This suggests that the observed wage inequality between the two labor forces is more likely to result from a segmentation of the labor market between workers having the required skills and characteristics to use novel technologies, and

\footnotetext{
${ }^{10}$ Results from the quantile regressions with interacted variables are available from the authors upon request.

${ }^{11} \mathrm{We}$ assume that all workers have the labor market characteristics of the modern workforce and capture the gap attributable to a divergence in the rewards to these characteristics. Alternatively, we can do the same decomposition assuming that workers have the labor market characteristics of the traditional workforce. We did not find any significant differences between both definitions with the data at hand.
} 
those workers not having them. Therefore, analyzing aggregate earnings differentials between ICT users and non users leads to a selection problem.

\section{Quantile regression decomposition by occupation}

\subsection{Selectivity issue}

Our results suggest thus that it matters to address the potential bias due to selection. Ideally, we would like to rely on an instrumental variable strategy to correct the bias. This means that a variable strongly correlated with the use of ICT, but not with individual wage, is needed. Unfortunately, the French data do not offer any suitable instrument to correct the selectivity bias. Note that this difficulty is not specific to our study ${ }^{12}$. For instance, using panel data also from France, the different findings reported in Entorf et alii (1999) suggest that controlling for selectivity bias is not so important in France when investigating the impact of ICT on wages and employment, but these authors also treat as exogenous the use of new technologies in their different wage equations ${ }^{13}$.

As the use of ICT may be seen as a treatment, we first attempt to assess the importance of the bias using a "selection on observables" approach. On the basis of propensity score matching estimators, this method is expected to reduce the bias in the estimation of a treatment effect with observational data (Becker and Ichino, 2002). The idea is to compare individual wages between ICT-users and non ICT-users using treated and control subjects that have to be as similar as possible. The characteristics of the respondents are summarized into the propensity score, and the extent to which the bias is reduced depends on the quality of the control variables selected to compute the propensity score.

An important feature is that the means of each individual characteristic should not differ between treated and control units after the matching. This condition is needed for the balancing property to be satisfied, meaning that exposure to treatment has to be random for a given propensity score. That the balancing condition does not hold conditional on a set of observables suggests that selection is a problem on the basis of the information taken into account to calculate the propensity score. When turning to the data, we first consider the whole sample and attempt to explain the probability for a respondent to be an ICT-user as a

\footnotetext{
${ }^{12}$ For further insights on the selectivity issue, see in particular Krueger (1993), DiNardo and Pischke (1997), and or Lee and Kim (2004). In these studies, there is no appropriate instrumental variable for computer use that would allow a direct estimation of the technological premium. To address the possibility of unobserved heterogeneity, DiNardo and Pischke (1997) introduce additional control variables like parental background and achievement scores in their wage regressions. They also point out the necessity to include a detailed set of occupation dummies, as we do in this section.
} 
function of individual characteristics using a Probit model. The different covariates are gender, age, seniority, levels of education, size of the firm and occupational dummies.

Despite intensive efforts, we never succeed in finding an appropriate specification of the propensity score, i.e. a specification satisfying the balancing property. In particular, there were always some differences by occupations between treated and control individuals. This is undoubtedly due to the fact that the use of ICT in the workplace strongly depends on the type of occupation. We thus choose to implement a more disaggregated analysis by occupations. Specifically, we examine the technological premium within six types of occupations: managers, intermediate professionals, technicians, employees, skilled production workers and unskilled production workers.

The idea is the following one. Individuals apply to jobs implying or not the use of ICT on the basis of the potential wage they might earn. In this sense, all individuals applying, for example, to manager positions expect to use at least a computer at their job, since this type of occupation generally implies the use of novel technologies (see Figure 2). However, it may happen that the firm offering the manager position has set up a policy such that none of the managers uses computers since this task is implemented by their secretaries, the role of the manager being exclusively to coordinate the team and give orders. In this case, even if the worker applied to the job expecting to use a computer and expecting a particular wage, the use of a computer does not depend on her.

Interestingly, we succeed easily in finding a suitable specification of the propensity score once considering the different occupational groups ${ }^{14}$. This indeed suggests that an analysis by occupations is likely to partially solve the selection problem, or at least to reduce significantly the underlying bias. As the balancing property is satisfied for each occupation (the common support condition being imposed), we then turn to a kernel matching estimator to evaluate the effect of being an ICT-user on the monthly wage (Heckman et alii, 1998). The different results of the kernel matching method are described in Table 5. For the sake of comparison, we also report the coefficient of the technological dummy given by an OLS regression for each occupation.

\section{Insert Table 5 here}

\footnotetext{
${ }^{13}$ See in particular Section 4 (Entorf et alii, 1999). As these authors use panel data, they are able to control for unobserved heterogeneity through the use of fixed effect regressions.

${ }^{14}$ The exact specification for the Probit model accounts for gender, age (25 and less, 26-35, 36-45, 46-55, more than 55), seniority (5 and less, 6 to 10,11 to 15,16 to 20, more than 20), education (no degree, BEPC,; CAPBEP, Baccalaureate, undergraduate, graduate-postgraduate), French citizenship, firm's size (1-19 employees, $20 *-49,50-99,100-499,500-1000$, more than 1000), and two interacted variables resulting from multiplying
} 
seniority respectively by gender and French citizenship. For the manager group, we also add the product of the age and gender variables. Detailed results are available upon request.

${ }^{15}$ The gap between the exogenous premium and the ATT estimate is in fact very low for each occupation, less than $1 \%$ on average. The largest difference $(1.5 \%)$ is observed among low-skilled workers. 
partitions provided by the indicators MODERN2 and MODERN3, for which we have respectively $79 \%$ and $62 \%$ of managers classified as modern ${ }^{16}$.

\section{Insert Table 5 here}

The passage from two to three technologies constitutes a breaking point in the composition of the technological premium. Whereas for all managers using at least one or two technologies the technological premium along the distribution is mostly explained by the divergence in the returns to identical characteristics, as soon as we fix the use of three technologies as a threshold value to become modern worker, the technological premium along the distribution is increasingly explained by the divergence in the labor market characteristics between ICT users and non users. This is probably due to the fact that, in occupations where ICT are so widely distributed, the use of one or two novel technologies does not really represent a clear differential characteristic. We must go up to three technologies to have a real signalling of a worker with particular characteristics.

Among intermediate professions, the divergence in the returns to identical characteristics explains most of the technological premium along the distribution when the indicators we use are MODERN1 and MODERN2. However, when considering the use of three technologies as the threshold value for classifying a worker as modern, we find that the divergence in the labor market characteristics explains an increasing proportion of the premium as we move up in the wage distribution.

Finally, for technicians, the composition of the premium is similar to the other two highly paid occupations. With a large definition of high-tech workers (either MODERN1 or MODERN2), the estimated wage differential between modern and traditional technicians is mainly due to differences in the rewards to identical observed characteristics. However, when considering a tighter definition of modernity (MODERN3), the divergence in the labor market characteristics increases its importance as explicative factor of the technical premium.

In sum, for the three highly paid occupations, we find that the premium linked to the use of novel technologies (unexplained part of the wage gap) is higher at the top of the conditional wage distribution than at the bottom ${ }^{17}$. Interestingly, the passage from two to three technologies constitutes a clear breakpoint when we partition the highly paid labor force between modern and traditional workers. When we consider as traditional workers all those individuals not using any ICT or using only one of them, earnings differentials between

\footnotetext{
${ }^{16}$ Nevertheless, we find that results provided by MODERN1 and MODERN2 are fairly similar, and it is rather the use of a third technology (MODERN3) that constitutes a threshold value in our findings.

${ }^{17}$ We find a kind of U-shaped evolution only for intermediate professions.
} 
modern and traditional workers are mostly explained by differences in the returns to identical characteristics. In contrast, when traditional workers are all individuals using less than three ICT, differences in the labor market characteristics between modern and traditional workers increasingly justify the earnings differentials between both populations as we move up in the wage distribution. Again, the wide presence of ICT among these occupations makes the use of at least three ICT a threshold point.

\subsection{Middle and low wage positions}

Middle paid jobs mainly correspond to employees. According to Autor et alii (2005) or Goos and Manning (2003), these positions stand for routine tasks (manual or cognitive), where labor input has been progressively substituted by novel technologies as the relative price of labor has increased. Low paid jobs, defined as skilled and unskilled production workers in our data, correspond to manual non routine positions. Since both middle and low paid jobs are much less intensive in novel technologies than highly paid positions, we expect people employing ICT and occupying middle and low paid positions to have different characteristics with respect to non ICT users.

This expectation is borne out for the employees. Most of the estimated wage gap is explained by the objective difference in the labor market characteristics between modern and traditional employees. To be coherent with Autor et alii (2005), it seems that those employees who have managed to keep their position and use novel technologies have completely different characteristics with respect to those not using ICT, which are likely to be progressively substituted by computer capital.

The situation for skilled and unskilled production workers is somewhat striking. Given the small proportion of users within these occupations, we expected to find that wage differentials between modern and traditional workers were mainly due to a divergence in the characteristics between ICT users and non users. However, for skilled production workers, we find that when using the indicators MODERN2 or MODERN3, the estimated wage differential along the distribution is almost equally explained by the divergence in the objective characteristics and by the divergence in the returns to these characteristics. When considering the indicator MODERN1, the divergence in the returns to identical characteristics becomes the main factor responsible for the estimated gap at the top of the distribution. 
At the bottom of the conditional wage distribution of unskilled workers, most of the estimated technological gap is due to differences in the returns to given characteristics. As we move up in the distribution, the role of objective differences progressively increases to become predominant.

In sum, while for middle paid occupations (routine positions), the divergence in the labor market characteristics of ICT users and non users essentially explains most of the earning differentials between both populations along the distribution, in manual non routine positions the premium linked to the use of ICT responds essentially to a divergence in the returns to identical characteristics. We believe this result is striking since, in low paid occupations, ICT are not extremely diffused. We expected, therefore, that people having access to them should have different labor market characteristics. This does not seem to be the case. It may be that labor market characteristics among skilled and unskilled production workers are fairly similar and that the use of ICT responds rather to some unobservable characteristics. In this case, two skilled (unskilled) workers, apparently identical, may be rewarded differently depending on the use of ICT simply because they may actually differ in some characteristics that we do not manage to observe and that determine the use of ICT. But again, it is not possible to account for the selection bias due to unobservables with the data.

\section{Concluding comments}

The purpose of this paper was to gain insight on the effects of new technologies on wage inequalities. Traditionally, all the interest of the literature has been focused on average wage inequalities between ICT users and non users. This contribution provides a more complete picture on the effects of novel technologies on wage inequalities, by focusing on the technological gap along the earnings distribution in France. At the aggregate level, most of the gap results from a divergence in the labor market characteristics between high-tech and low-tech workforces, pointing towards the existence of a selection of workers.

A more accurate description of the technological premium by occupations allows to better account for the selectivity issue. In highly paid professions characterized by the large presence of novel technologies, the use of three or more ICT constitutes a threshold value in the composition of the technological premium. From this value, the premium along the distribution increasingly responds to individual characteristics, whereas for larger definitions of modern workers earnings differentials are mainly explained by a divergence in the rewards to identical characteristics. In middle paid occupations, the technological gap is more important than in highly paid positions and it results essentially from a divergence in the 
objective characteristics. In contrast, in low paid positions where ICT are scarce differences in the labor market characteristics play a predominant role in explaining this gap only at the top of the conditional distribution.

Finally, we would like to point out some shortcomings of our analysis. First, while we turn to a "selection on observables" approach when estimating the magnitude of the technological premium for different occupations, we were not able to correct for selection bias due to unobservable factors in our wage regressions (due to the lack of appropriate variables to satisfy exclusion restrictions). Despite our efforts to account for the selection bias (on the basis of observable factors), it is unclear to know how a correction of selection on unobservables would affect our results. Secondly, we did not control for unobserved firm heterogeneity. With matched employer-employee data, it would be possible to introduce firm fixed effects into the wage equation and to better account for the fact that high-wage workers may be in high-wage firms. Third, it would be of interest to know whether our findings also apply for the last five years, an issue that we left for future research. We leave all these issues for future research. 


\section{References}

Albrecht, J., Björklund, A. and Vroman, S. (2003) Is there a Glass Ceiling in Sweden?, Journal of Labor Economics, 21, 145-177.

Autor, D., Katz, L. and Kearney, M. (2005) Trends in the U.S. Wage Inequality: Re-Assessing the Revisionists, NBER Working Paper, 11627.

Autor, D., Levy, F. and Kearney, M. (2006) The Polarization of the US Labor Market, American Economic Review, 96, 189-194.

Autor, D., Katz, L. and Krueger, A.B. (1998) Computing Inequality: Have Computers Changed the Labour Market?, Quarterly Journal of Economics, 113, 1169-1213.

Becker, S. and Ichino, A. (2002) Estimation of Average Treatment Effects Based on Propensity Scores, The Stata Journal, 2, 358-377.

Caroli, E. and Van Reenen, J. (2001) Skilled Biased Technological Change? Evidence from a Panel of British and French Establishments, Quarterly Journal of Economics, 116, 1449-1492.

Davis, S. and Haltiwanger, J. (1991) Wage Dispersion Between and Within U.S. Manufacturing Plants, Brookings Papers on Economic Activity. Microeconomics, 115-200.

DiNardo, J.E. and Pischke, J.-S. (1997) The Returns to Computer Use Revisited: Have Pencils Changed the Wage Structure Too ?, Quarterly Journal of Economics, 112, 291-303.

Entorf, J., Gollac, M. and Kramarz, F. (1999) New Technologies, Wages, and Worker Selection, Journal of Labor Economics, 17, 464-491.

Goos, M. and Manning, A. (2003) Lousy and Lovely Jobs: the Rising Polarization of Work in Britain, CEPR Discussion Paper, 604.

Heckman, J., Ichimura, H., Smith, J. and Todd, P. (1998) Characterizing Selection Bias Using Experimental Data, Econometrica, 66, 1017-1098.

Koenker, R. and Bassett, G. (1978) Regression Quantiles, Econometrica, 46, 33-50.

Jellal, M., Nordman, C. and Wolff, F.C. (2008) Evidence on the Glass Ceiling in France using Matched Worker-Firm Data, Applied Economics, forthcoming.

Krueger, A. (1993) How Computers Have Changed the Wages Structure: Evidence from Microdata, 1984-1989, Quarterly Journal of Economics, 108, 33-60.

Krusell, P., Ohanian, L., Rios-Rull, J.V. and Violante, G.L. (2000) Capital Skill Complementarity and Inequality: A Macroeconomic Analysis, Econometrica, 68, 1029-1053.

Lee, S.H. and Kim, J. (2004) Has the Internet Changed the Wage Structure too?, Labour Economics, 11, 119-127.

Lemieux, T. (2006) Increasing Residual Wage Inequality: Composition Effects, Noisy Data or Rising Demand for Skill?, American Economic Review, 96, 461-498.

Machado, J.A.F. and Mata, J. (2005) Counterfactual Decomposition of Changes in Wage Distribution using Quantile Regression, Journal of Applied Econometrics, 20, 445-465.

Oaxaca, R.L. and Ransom M.R. (1994) On Discrimination and the Decomposition of Wage Differentials, Journal of Econometrics, 61, 5-21. 
Table 1. Descriptive statistics of the sample

A. By MODERN1, MODERN2 and MODERN3 indicators

\begin{tabular}{|l|c|c|c|c|c|c|}
\hline \multirow{2}{*}{ Variables } & \multicolumn{2}{|c|}{ MODERN1 } & \multicolumn{2}{c|}{ MODERN2 } & \multicolumn{2}{c|}{ MODERN3 } \\
\cline { 2 - 7 } & Traditional & Modern & Traditional & Modern & Traditional & Modern \\
\hline Female & 0.263 & 0.393 & 0.303 & 0.378 & 0.324 & 0.352 \\
Age & 38.477 & 38.543 & 38.384 & 38.716 & 38.400 & 38.836 \\
Years of experience & 9.930 & 11.644 & 10.159 & 11.911 & 10.348 & 12.248 \\
Diploma: no degree & 0.415 & 0.145 & 0.365 & 0.125 & 0.330 & 0.107 \\
Diploma: BEPC & 0.065 & 0.066 & 0.065 & 0.067 & 0.066 & 0.063 \\
Diploma: CAP - BEP & 0.409 & 0.316 & 0.402 & 0.293 & 0.390 & 0.273 \\
Diploma: Baccalaureate & 0.067 & 0.182 & 0.091 & 0.187 & 0.109 & 0.182 \\
Diploma: Undergraduate & 0.031 & 0.165 & 0.052 & 0.180 & 0.070 & 0.193 \\
Diploma: Graduate - postgraduate & 0.013 & 0.126 & 0.026 & 0.148 & 0.036 & 0.181 \\
Occupation: Managers & 0.023 & 0.194 & 0.039 & 0.232 & 0.056 & 0.280 \\
Occupation: Intermediates & 0.059 & 0.165 & 0.081 & 0.169 & 0.099 & 0.162 \\
Occupation: Technicians & 0.055 & 0.152 & 0.068 & 0.167 & 0.077 & 0.190 \\
Occupation: Employees & 0.155 & 0.269 & 0.188 & 0.258 & 0.207 & 0.239 \\
Occupation: High-skilled workers & 0.487 & 0.177 & 0.435 & 0.144 & 0.397 & 0.110 \\
Occupation: Low-skilled workers & 0.222 & 0.043 & 0.189 & 0.029 & 0.165 & 0.019 \\
French citizenship & 0.910 & 0.973 & 0.924 & 0.974 & 0.934 & 0.972 \\
Firm's size: 1-19 employees & 0.280 & 0.172 & 0.276 & 0.142 & 0.256 & 0.131 \\
Firm's size: 20-49 employees & 0.173 & 0.125 & 0.169 & 0.115 & 0.163 & 0.104 \\
Firm's size: 50-99 employees & 0.093 & 0.074 & 0.089 & 0.074 & 0.088 & 0.068 \\
Firm's size: 100-499 employees & 0.197 & 0.217 & 0.198 & 0.223 & 0.204 & 0.218 \\
Firm's size: 500-1000 employees & 0.052 & 0.078 & 0.055 & 0.083 & 0.059 & 0.085 \\
Firm's size: > 1000 employees & 0.126 & 0.293 & 0.140 & 0.332 & 0.162 & 0.365 \\
\hline Number of observations & 4156 & 4638 & 5407 & 3387 & 6547 & 2247 \\
\hline
\end{tabular}


B. BY COMPUTERI, COMPUTER2, TERMINAL,INTERNET ROBOT, OTHERS, ORDERINT and ORDEREXT indicators

\begin{tabular}{|c|c|c|c|c|c|c|c|c|c|c|c|c|c|c|c|c|}
\hline \multirow[b]{2}{*}{ Variables } & \multicolumn{2}{|c|}{ COMPUTER1 } & \multicolumn{2}{|c|}{ COMPUTER2 } & \multicolumn{2}{|c|}{ TERMINAL } & \multicolumn{2}{|c|}{ INTERNET } & \multicolumn{2}{|c|}{ ROBOT } & \multicolumn{2}{|c|}{ OTHERS } & \multicolumn{2}{|c|}{ ORDERINT } & \multicolumn{2}{|c|}{ ORDEREXDT } \\
\hline & 0 & 1 & 0 & 1 & 0 & 1 & 0 & 1 & 0 & 1 & 0 & 1 & 0 & 1 & 0 & 1 \\
\hline Female & 0.296 & 0.393 & 0.320 & 0.375 & 0.329 & 0.340 & 0.335 & 0.283 & 0.338 & 0.121 & 0.333 & 0.314 & 0.318 & 0.368 & 0.322 & 0.381 \\
\hline Age & 38.429 & 38.653 & 38.590 & 38.199 & 38.331 & 39.232 & 38.620 & 37.003 & 38.563 & 36.790 & 38.549 & 38.115 & 38.317 & 39.020 & 38.440 & 38.869 \\
\hline Years of experience & 10.093 & 12.101 & 10.834 & 10.832 & 10.355 & 12.745 & 10.930 & 9.497 & 10.827 & 11.054 & 10.816 & 11.028 & 10.178 & 12.543 & 10.663 & 11.693 \\
\hline Diploma: no degree & 0.356 & 0.130 & 0.314 & 0.111 & 0.306 & 0.140 & 0.288 & 0.056 & 0.273 & 0.253 & 0.286 & 0.131 & 0.332 & 0.118 & 0.307 & 0.101 \\
\hline Diploma: BEPC & 0.066 & 0.065 & 0.066 & 0.064 & 0.062 & 0.080 & 0.068 & 0.034 & 0.065 & 0.074 & 0.066 & 0.065 & 0.066 & 0.063 & 0.066 & 0.065 \\
\hline Diploma: CAP - BEP & 0.399 & 0.293 & 0.374 & 0.303 & 0.371 & 0.316 & 0.377 & 0.124 & 0.357 & 0.471 & 0.363 & 0.329 & 0.390 & 0.281 & 0.384 & 0.240 \\
\hline Diploma: Baccalaureate & 0.095 & 0.184 & 0.112 & 0.191 & 0.114 & 0.182 & 0.126 & 0.151 & 0.128 & 0.113 & 0.123 & 0.183 & 0.107 & 0.180 & 0.115 & 0.190 \\
\hline Diploma: Undergraduate & 0.055 & 0.180 & 0.079 & 0.188 & 0.086 & 0.162 & 0.091 & 0.242 & 0.102 & 0.070 & 0.096 & 0.163 & 0.069 & 0.186 & 0.081 & 0.205 \\
\hline Diploma: Graduate - postgraduate & 0.029 & 0.148 & 0.055 & 0.143 & 0.061 & 0.120 & 0.050 & 0.394 & 0.074 & 0.019 & 0.068 & 0.129 & 0.035 & 0.171 & 0.048 & 0.199 \\
\hline Occupation: Managers & 0.045 & 0.230 & 0.087 & 0.219 & 0.088 & 0.215 & 0.083 & 0.528 & 0.116 & 0.027 & 0.103 & 0.224 & 0.057 & 0.258 & 0.072 & 0.321 \\
\hline Occupation: Intermediates & 0.090 & 0.158 & 0.095 & 0.195 & 0.105 & 0.155 & 0.113 & 0.147 & 0.117 & 0.035 & 0.113 & 0.134 & 0.095 & 0.168 & 0.104 & 0.168 \\
\hline Occupation: Technicians & 0.071 & 0.166 & 0.085 & 0.190 & 0.085 & 0.188 & 0.101 & 0.176 & 0.104 & 0.171 & 0.098 & 0.190 & 0.082 & 0.170 & 0.095 & 0.160 \\
\hline Occupation: Employees & 0.186 & 0.265 & 0.206 & 0.250 & 0.208 & 0.246 & 0.222 & 0.125 & 0.221 & 0.031 & 0.214 & 0.232 & 0.204 & 0.244 & 0.205 & 0.264 \\
\hline Occupation: High-skilled workers & 0.425 & 0.150 & 0.373 & 0.127 & 0.363 & 0.166 & 0.345 & 0.020 & 0.318 & 0.514 & 0.338 & 0.168 & 0.395 & 0.136 & 0.373 & 0.074 \\
\hline Occupation: Low-skilled workers & 0.184 & 0.031 & 0.154 & 0.020 & 0.152 & 0.029 & 0.136 & 0.003 & 0.125 & 0.222 & 0.135 & 0.052 & 0.167 & 0.024 & 0.150 & 0.013 \\
\hline French citizenship & 0.926 & 0.974 & 0.934 & 0.980 & 0.936 & 0.975 & 0.943 & 0.953 & 0.944 & 0.930 & 0.941 & 0.971 & 0.933 & 0.971 & 0.938 & 0.971 \\
\hline Firm's size: 1-19 employees & 0.278 & 0.132 & 0.223 & 0.231 & 0.248 & 0.129 & 0.228 & 0.166 & 0.229 & 0.062 & 0.228 & 0.179 & 0.269 & 0.108 & 0.236 & 0.165 \\
\hline Firm's size: 20-49 employees & 0.167 & 0.116 & 0.151 & 0.136 & 0.157 & 0.111 & 0.149 & 0.134 & 0.149 & 0.125 & 0.150 & 0.123 & 0.166 & 0.101 & 0.155 & 0.114 \\
\hline Firm's size: 50-99 employees & 0.088 & 0.075 & 0.086 & 0.073 & 0.086 & 0.071 & 0.084 & 0.080 & 0.083 & 0.089 & 0.085 & 0.061 & 0.088 & 0.071 & 0.087 & 0.064 \\
\hline Firm's size: 100-499 employees & 0.196 & 0.227 & 0.210 & 0.199 & 0.203 & 0.225 & 0.209 & 0.184 & 0.205 & 0.276 & 0.207 & 0.212 & 0.201 & 0.224 & 0.208 & 0.205 \\
\hline Firm's size: 500-1000 employees & 0.054 & 0.084 & 0.066 & 0.063 & 0.059 & 0.091 & 0.064 & 0.080 & 0.065 & 0.082 & 0.065 & 0.074 & 0.055 & 0.093 & 0.063 & 0.075 \\
\hline Firm's size: > 1000 employees & 0.139 & 0.342 & 0.209 & 0.232 & 0.181 & 0.344 & 0.206 & 0.321 & 0.210 & 0.350 & 0.207 & 0.290 & 0.150 & 0.379 & 0.188 & 0.342 \\
\hline Number of observations & 5551 & 3243 & 7024 & 1770 & 7031 & 1763 & 8203 & 591 & 8537 & 257 & 8040 & 754 & 6356 & 2438 & 7334 & 1460 \\
\hline
\end{tabular}

Number of observations

Source: Labor Force survey and Complementary survey on Working Conditions, 1998

Note: MODERN1 stands for at least one ICT, MODERN2 for at least 2 ICT, and MODERN 3 for at least 3 ICT. 
Table 2. Descriptive statistics by occupation, with MODERN1

\begin{tabular}{|c|c|c|c|c|c|c|c|c|c|c|c|c|}
\hline \multirow[t]{2}{*}{ Variables } & \multicolumn{2}{|c|}{ Managers } & \multicolumn{2}{|c|}{ Intermediate prof. } & \multicolumn{2}{|c|}{ Technicians } & \multicolumn{2}{|c|}{ Employees } & \multicolumn{2}{|c|}{ Skilled prod. workers } & \multicolumn{2}{|c|}{ Unskilled prod. workers } \\
\hline & Tradit. & Modern & Tradit. & Modern & Tradit. & Tradit. & Modern & Tradit. & Modern & Tradit. & Tradit. & Modern \\
\hline Female & 0.232 & 0.242 & 0.413 & 0.529 & 0.053 & 0.098 & 0.712 & 0.780 & 0.099 & 0.122 & 0.323 & 0.286 \\
\hline Age & 47.674 & 41.229 & 41.607 & 38.421 & 42.004 & 38.908 & 37.240 & 37.550 & 39.093 & 38.158 & 35.333 & 33.387 \\
\hline Years of experience & 15.011 & 11.759 & 9.968 & 10.647 & 13.414 & 13.360 & 8.283 & 10.890 & 10.644 & 12.931 & 8.120 & 8.276 \\
\hline Diploma: no degree & 0.147 & 0.032 & 0.138 & 0.094 & 0.273 & 0.112 & 0.403 & 0.152 & 0.415 & 0.283 & 0.560 & 0.362 \\
\hline Diploma: BEPC & 0.074 & 0.050 & 0.097 & 0.066 & 0.040 & 0.045 & 0.095 & 0.090 & 0.050 & 0.061 & 0.072 & 0.085 \\
\hline Diploma: CAP - BEP & 0.211 & 0.123 & 0.308 & 0.211 & 0.542 & 0.340 & 0.358 & 0.355 & 0.482 & 0.540 & 0.300 & 0.332 \\
\hline Diploma: Baccalaureate & 0.158 & 0.123 & 0.150 & 0.244 & 0.070 & 0.194 & 0.104 & 0.243 & 0.045 & 0.091 & 0.056 & 0.166 \\
\hline Diploma: Undergraduate & 0.116 & 0.197 & 0.251 & 0.266 & 0.057 & 0.268 & 0.033 & 0.133 & 0.006 & 0.023 & 0.010 & 0.045 \\
\hline Diploma: Graduate - postgraduate & 0.295 & 0.474 & 0.057 & 0.119 & 0.018 & 0.041 & 0.008 & 0.026 & 0.001 & 0.002 & 0.002 & 0.010 \\
\hline French citizenship & 0.968 & 0.973 & 0.968 & 0.975 & 0.921 & 0.973 & 0.913 & 0.983 & 0.909 & 0.966 & 0.887 & 0.935 \\
\hline Firm’s size: 1-19 employees & 0.242 & 0.128 & 0.263 & 0.245 & 0.216 & 0.102 & 0.333 & 0.246 & 0.302 & 0.105 & 0.232 & 0.146 \\
\hline Firm's size: $20-49$ employees & 0.158 & 0.126 & 0.194 & 0.110 & 0.194 & 0.116 & 0.115 & 0.139 & 0.187 & 0.125 & 0.174 & 0.126 \\
\hline Firm's size: 50-99 employees & 0.063 & 0.083 & 0.105 & 0.073 & 0.137 & 0.076 & 0.090 & 0.058 & 0.089 & 0.082 & 0.093 & 0.106 \\
\hline Firm's size: $100-499$ employees & 0.200 & 0.218 & 0.162 & 0.220 & 0.203 & 0.255 & 0.148 & 0.190 & 0.194 & 0.227 & 0.245 & 0.201 \\
\hline Firm's size: $500-1000$ employees & 0.074 & 0.080 & 0.077 & 0.064 & 0.040 & 0.081 & 0.030 & 0.067 & 0.052 & 0.097 & 0.060 & 0.090 \\
\hline Firm's size: > 1000 employees & 0.179 & 0.333 & 0.109 & 0.223 & 0.176 & 0.341 & 0.137 & 0.245 & 0.113 & 0.341 & 0.133 & 0.302 \\
\hline Number of observations & 95 & 900 & 247 & 763 & 227 & 706 & 643 & 1249 & 2022 & 821 & 922 & 199 \\
\hline
\end{tabular}

Source: Labor Force survey and Complementary survey on Working Conditions, 1998. 
Table 3. Quantile regression estimates of the log-wage pooled sample, with MODERN1

\begin{tabular}{|c|c|c|c|c|c|c|}
\hline Variables & $\begin{array}{c}10^{\text {th }} \\
\text { percentile }\end{array}$ & $\begin{array}{c}25^{\text {th }} \\
\text { percentile }\end{array}$ & $\begin{array}{c}50^{\text {th }} \\
\text { percentile }\end{array}$ & $\begin{array}{c}75^{\text {th }} \\
\text { percentile }\end{array}$ & $\begin{array}{c}90^{\text {th }} \\
\text { percentile }\end{array}$ & Mean (OLS) \\
\hline MODERN1 & $\begin{array}{c}0.077 * * * \\
(6.48)\end{array}$ & $\begin{array}{c}0.066^{* * *} \\
(7.41)\end{array}$ & $\begin{array}{c}0.071 * * * \\
(11.15)\end{array}$ & $\begin{array}{c}0.064 * * * \\
(8.10)\end{array}$ & $\begin{array}{c}0.078 * * * \\
(6.25)\end{array}$ & $\begin{array}{c}0.073 * * * \\
(10.02)\end{array}$ \\
\hline Female & $\begin{array}{c}-0.083 * * * \\
(6.44)\end{array}$ & $\begin{array}{c}-0.098 * * * \\
(10.45)\end{array}$ & $\begin{array}{c}-0.121 * * * \\
(18.50)\end{array}$ & $\begin{array}{c}-0.147 * * * \\
(18.91)\end{array}$ & $\begin{array}{c}-0.172 * * * \\
(14.83)\end{array}$ & $\begin{array}{c}-0.121 * * * \\
(16.21)\end{array}$ \\
\hline Age & $\begin{array}{c}0.081 * * * \\
(18.18)\end{array}$ & $\begin{array}{c}0.049 * * * \\
(16.59)\end{array}$ & $\begin{array}{c}0.032 * * * \\
(16.29)\end{array}$ & $\begin{array}{c}0.028 * * * \\
(12.03)\end{array}$ & $\begin{array}{c}0.025 * * * \\
(7.08)\end{array}$ & $\begin{array}{c}0.053 * * * \\
(23.56)\end{array}$ \\
\hline Age squared & $\begin{array}{c}-0.092 * * * \\
(17.26)\end{array}$ & $\begin{array}{c}-0.054 * * * \\
(14.86)\end{array}$ & $\begin{array}{c}-0.034 * * * \\
(13.56)\end{array}$ & $\begin{array}{c}-0.026 * * * \\
(8.93)\end{array}$ & $\begin{array}{c}-0.021 * * * * \\
(4.63)\end{array}$ & $\begin{array}{c}-0.056^{* * * *} \\
(19.77)\end{array}$ \\
\hline Seniority & $\begin{array}{c}0.009 * * * \\
(5.05)\end{array}$ & $\begin{array}{c}0.012 * * * \\
(8.81)\end{array}$ & $\begin{array}{c}0.012 * * * \\
(12.98)\end{array}$ & $\begin{array}{c}0.012 * * * \\
(10.03)\end{array}$ & $\begin{array}{c}0.007 * * * \\
(4.08)\end{array}$ & $\begin{array}{c}0.010^{* * * *} \\
(9.71)\end{array}$ \\
\hline Seniority squared & $\begin{array}{c}-0.010 * * \\
(2.00)\end{array}$ & $\begin{array}{c}-0.019 * * * \\
(4.87)\end{array}$ & $\begin{array}{c}-0.021 * * * \\
(7.50)\end{array}$ & $\begin{array}{c}-0.022 * * * \\
(6.13)\end{array}$ & $\begin{array}{c}-0.013 * * \\
(2.26)\end{array}$ & $\begin{array}{c}-0.017 * * * \\
(5.33)\end{array}$ \\
\hline Diploma: BEPC & $\begin{array}{c}0.072 * * * \\
(3.53)\end{array}$ & $\begin{array}{c}0.059 * * * \\
(3.85)\end{array}$ & $\begin{array}{c}0.069 * * * \\
\quad(6.29)\end{array}$ & $\begin{array}{c}0.070 * * * \\
\quad(5.25)\end{array}$ & $\begin{array}{c}0.090 * * * \\
(4.52)\end{array}$ & $\begin{array}{c}0.084 * * * \\
(6.69)\end{array}$ \\
\hline Diploma: CAP - BEP & $\begin{array}{c}0.092 * * * \\
(7.50)\end{array}$ & $\begin{array}{c}0.074 * * * \\
(8.11)\end{array}$ & $\begin{array}{c}0.063 * * * \\
(9.56)\end{array}$ & $\begin{array}{c}0.066^{* * *} * \\
(8.26)\end{array}$ & $\begin{array}{c}0.067 * * * \\
(5.42)\end{array}$ & $\begin{array}{c}0.091 * * * \\
(12.22)\end{array}$ \\
\hline Diploma: Baccalaureate & $\begin{array}{c}0.122 * * * \\
(6.90)\end{array}$ & $\begin{array}{c}0.097 * * * \\
(7.48)\end{array}$ & $\begin{array}{c}0.078 * * * \\
(8.38)\end{array}$ & $\begin{array}{c}0.090 * * * \\
(7.86)\end{array}$ & $\begin{array}{c}0.076 * * * \\
(4.37)\end{array}$ & $\begin{array}{c}0.122 * * * \\
(11.49)\end{array}$ \\
\hline Diploma: Undergraduate & $\begin{array}{c}0.192 * * * \\
\quad(9.44)\end{array}$ & $\begin{array}{c}0.159 * * * \\
(10.53)\end{array}$ & $\begin{array}{c}0.136 * * * \\
(12.65)\end{array}$ & $\begin{array}{c}0.157 * * * \\
(12.04)\end{array}$ & $\begin{array}{c}0.162 * * * \\
(7.99)\end{array}$ & $\begin{array}{c}0.185^{* * *} * \\
(15.14)\end{array}$ \\
\hline Diploma: Graduate - postgraduate & $\begin{array}{c}0.201 * * * \\
(7.61)\end{array}$ & $\begin{array}{c}0.170 * * * \\
(8.92)\end{array}$ & $\begin{array}{c}0.206 * * * \\
(15.32)\end{array}$ & $\begin{array}{c}0.284 * * * \\
(17.53)\end{array}$ & $\begin{array}{c}0.294 * * * \\
(11.62)\end{array}$ & $\begin{array}{c}0.268 * * * \\
(17.56)\end{array}$ \\
\hline Occupation: Managers & $\begin{array}{c}0.590 * * * \\
(23.23)\end{array}$ & $\begin{array}{c}0.637 * * * \\
(33.30)\end{array}$ & $\begin{array}{c}0.709 * * * \\
(52.89)\end{array}$ & $\begin{array}{c}0.783 * * * \\
(49.69)\end{array}$ & $\begin{array}{c}0.904 * * * \\
(37.11)\end{array}$ & $\begin{array}{c}0.714 * * * \\
(46.83)\end{array}$ \\
\hline Occupation: Intermediates & $\begin{array}{c}0.248^{* * *} * \\
(10.97)\end{array}$ & $\begin{array}{c}0.263 * * * \\
(15.44)\end{array}$ & $\begin{array}{c}0.324 * * * \\
(26.81)\end{array}$ & $\begin{array}{c}0.369 * * * \\
(25.41)\end{array}$ & $\begin{array}{c}0.450 * * * \\
(20.15)\end{array}$ & $\begin{array}{c}0.325^{* * *} * \\
(23.66)\end{array}$ \\
\hline Occupation: Technicians & $\begin{array}{c}0.265 * * * \\
(12.50)\end{array}$ & $\begin{array}{c}0.253 * * * \\
(15.46)\end{array}$ & $\begin{array}{c}0.283 * * * \\
(24.22)\end{array}$ & $\begin{array}{c}0.329 * * * \\
(23.72)\end{array}$ & $\begin{array}{c}0.340 * * * \\
(16.22)\end{array}$ & $\begin{array}{c}0.298 * * * \\
(22.49)\end{array}$ \\
\hline Occupation: Employees & $\begin{array}{c}0.094 * * * \\
(4.68)\end{array}$ & $\begin{array}{c}0.074 * * * \\
(4.94)\end{array}$ & $\begin{array}{c}0.102 * * * \\
(9.55)\end{array}$ & $\begin{array}{c}0.142^{* * *} \\
(11.06)\end{array}$ & $\begin{array}{c}0.169 * * * \\
(8.72)\end{array}$ & $\begin{array}{c}0.116^{* * *} \\
(9.49)\end{array}$ \\
\hline Occupation: High-skilled workers & $\begin{array}{c}0.118 * * * \\
(7.41)\end{array}$ & $\begin{array}{c}0.098 * * * \\
(8.05)\end{array}$ & $\begin{array}{c}0.096 * * * \\
(11.04)\end{array}$ & $\begin{array}{c}0.106 * * * \\
(10.23)\end{array}$ & $\begin{array}{c}0.116 * * * \\
(7.30)\end{array}$ & $\begin{array}{c}0.115^{* * *} \\
(11.63)\end{array}$ \\
\hline French citizenship & $\begin{array}{l}0.004 \\
(0.20)\end{array}$ & $\begin{array}{l}0.005 \\
(0.33)\end{array}$ & $\begin{array}{l}0.011 \\
(1.04)\end{array}$ & $\begin{array}{l}0.008 \\
(0.63)\end{array}$ & $\begin{array}{r}-0.027 \\
(1.35)\end{array}$ & $\begin{array}{r}-0.001 \\
(0.11)\end{array}$ \\
\hline Firm's size: $20-49$ employees & $\begin{array}{c}0.055^{* * *} \\
(3.74)\end{array}$ & $\begin{array}{c}0.026 * * \\
(2.37)\end{array}$ & $\begin{array}{c}0.032 * * * \\
(3.99)\end{array}$ & $\begin{array}{c}0.027 * * * \\
(2.77)\end{array}$ & $\begin{array}{c}0.040 * * * \\
(2.71)\end{array}$ & $\begin{array}{c}0.046^{* * *} * \\
(5.00)\end{array}$ \\
\hline Firm's size: 50-99 employees & $\begin{array}{c}0.054 * * * \\
(3.00)\end{array}$ & $\begin{array}{l}0.017 \\
(1.22)\end{array}$ & $\begin{array}{c}0.022 * * \\
(2.24)\end{array}$ & $\begin{array}{c}0.021^{*} \\
(1.75)\end{array}$ & $\begin{array}{r}-0.005 \\
(0.26)\end{array}$ & $\begin{array}{c}0.038 * * * \\
(3.34)\end{array}$ \\
\hline Firm's size: 100-499 employees & $\begin{array}{c}0.061 * * * \\
(4.42)\end{array}$ & $\begin{array}{c}0.043 * * * \\
(4.07)\end{array}$ & $\begin{array}{c}0.053 * * * \\
(6.96)\end{array}$ & $\begin{array}{c}0.036 * * * \\
(3.86)\end{array}$ & $\begin{array}{l}0.023 \\
(1.64)\end{array}$ & $\begin{array}{c}0.052 * * * \\
(5.98)\end{array}$ \\
\hline Firm's size: 500-1000 employees & $\begin{array}{c}0.099 * * * \\
(4.75)\end{array}$ & $\begin{array}{c}0.085 * * * \\
(5.41)\end{array}$ & $\begin{array}{c}0.070 * * * \\
(6.22)\end{array}$ & $\begin{array}{c}0.053 * * * \\
(3.94)\end{array}$ & $\begin{array}{c}0.054 * * * \\
(2.61)\end{array}$ & $\begin{array}{c}0.079 * * * \\
(6.19)\end{array}$ \\
\hline Firm's size: > 1000 employees & $\begin{array}{c}0.111 * * * \\
(7.33)\end{array}$ & $\begin{array}{c}0.094 * * * \\
(8.35)\end{array}$ & $\begin{array}{c}0.105 * * * \\
(12.99)\end{array}$ & $\begin{array}{c}0.095 * * * \\
(9.76)\end{array}$ & $\begin{array}{c}0.072 * * * \\
(4.87)\end{array}$ & $\begin{array}{c}0.094 * * * \\
(10.31)\end{array}$ \\
\hline Constant & $\begin{array}{c}6.433 * * * \\
(64.73)\end{array}$ & $\begin{array}{c}7.333 * * * \\
(110.57)\end{array}$ & $\begin{array}{c}7.857 * * * \\
(179.39)\end{array}$ & $\begin{array}{c}8.154 * * * \\
(158.41)\end{array}$ & $\begin{array}{c}8.291 * * * \\
(101.81)\end{array}$ & $\begin{array}{c}7.365 * * * \\
(147.99)\end{array}$ \\
\hline $\begin{array}{l}\text { Number of observations } \\
\text { Pseudo } R^{2}-R^{2}\end{array}$ & $\begin{array}{l}8794 \\
0.345 \\
\end{array}$ & $\begin{array}{l}8794 \\
0.364 \\
\end{array}$ & $\begin{array}{l}8794 \\
0.411 \\
\end{array}$ & $\begin{array}{l}8794 \\
0.454 \\
\end{array}$ & $\begin{array}{l}8794 \\
0.489 \\
\end{array}$ & $\begin{array}{l}8794 \\
0.643\end{array}$ \\
\hline
\end{tabular}

Source: Labor Force survey and Complementary survey on Working Conditions, 1998.

Quantile regression estimates, with absolute values of t-statistics in parentheses. Significance levels are respectively $1 \%(* * *), 5 \%$ $(* *)$, and $10 \%(*)$. The different regressions also include a set of 35 sectorial dummies. 
Table 4. Quantile decomposition of the log wage technological differential

\begin{tabular}{|c|c|c|c|c|c|c|c|c|c|}
\hline \multirow[t]{2}{*}{ Decomposition } & \multicolumn{3}{|c|}{$\begin{array}{l}\text { Difference in characteristics } \\
\beta^{t}\left(x^{m}-x^{t}\right)\end{array}$} & \multicolumn{3}{|c|}{$\begin{array}{c}\text { Difference in coefficients } \\
x^{m}\left(\beta^{m}-\beta^{t}\right)\end{array}$} & \multicolumn{3}{|c|}{$\begin{array}{c}\text { Total difference } \\
\beta^{n} x^{m}-\beta x^{t}\end{array}$} \\
\hline & MOD1 & MOD2 & MOD3 & MOD1 & MOD2 & MOD3 & MOD1 & MOD2 & MOD3 \\
\hline Percentile 10 & 0.2375 & 0.2699 & 0.306 & 0.1225 & 0.0726 & 0.0483 & 0.3601 & 0.3425 & 0.3543 \\
\hline Percentile 25 & 0.2437 & 0.2613 & 0.2768 & 0.0611 & 0.0573 & 0.0640 & 0.3049 & 0.3186 & 0.3408 \\
\hline Percentile 50 & 0.2615 & 0.2946 & 0.3232 & 0.0557 & 0.0390 & 0.0373 & 0.3172 & 0.3336 & 0.3605 \\
\hline Percentile 75 & 0.3104 & 0.3275 & 0.3427 & 0.0332 & 0.0330 & 0.0519 & 0.3436 & 0.3605 & 0.3946 \\
\hline Percentile 90 & 0.3257 & 0.3319 & 0.3595 & 0.0454 & 0.0629 & 0.0847 & 0.3711 & 0.3947 & 0.4441 \\
\hline Mean & 0.2891 & 0.3036 & 0.3198 & 0.0474 & 0.0454 & 0.0572 & 0.3365 & 0.3490 & 0.3769 \\
\hline
\end{tabular}

Source: Labor Force survey and Complementary survey on Working Conditions, 1998.

Note: MOD1 stands for at least one ICT, MOD2 for at least 2 ICT, and MOD3 for at least 3 ICT. 
Table 5. Propensity score estimates of the technological premium, by occupation

\begin{tabular}{|c|c|c|c|c|c|c|}
\hline \multirow[t]{2}{*}{ Technological premium } & \multicolumn{6}{|c|}{ Occupation } \\
\hline & Managers & Intermediates & Technicians & Employees & $\begin{array}{l}\text { High-skilled } \\
\text { workers }\end{array}$ & $\begin{array}{l}\text { Low-skilled } \\
\text { workers }\end{array}$ \\
\hline OLS regression & & & & & & \\
\hline Exogenous premium & $\begin{array}{c}0.079 * * \\
(2.00)\end{array}$ & $\begin{array}{c}0.076 * * * \\
(3.30)\end{array}$ & $\begin{array}{l}0.040^{*} \\
(1.90)\end{array}$ & $\begin{array}{c}0.162 * * * \\
(11.58)\end{array}$ & $\begin{array}{c}0.069 * * * \\
(7.51)\end{array}$ & $\begin{array}{l}0.110 * * * \\
(5.18)\end{array}$ \\
\hline Kernel matching estimator & & & & & & \\
\hline Unmatched & $\begin{array}{l}0.057 \\
(1.29)\end{array}$ & $\begin{array}{c}0.073 * * * \\
(2.94)\end{array}$ & $\begin{array}{c}0058^{* *} \\
(2.57)\end{array}$ & $\begin{array}{c}0.272 * * * \\
(17.66)\end{array}$ & $\begin{array}{c}0.111 * * * \\
(11.32)\end{array}$ & $\begin{array}{c}0.176 * * * \\
(6.72)\end{array}$ \\
\hline ATT & $\begin{array}{c}0.073^{*} \\
(1.86)\end{array}$ & $\begin{array}{c}0.075 * * * \\
(3.14)\end{array}$ & $\begin{array}{l}0.031 \\
(0.97)\end{array}$ & $\begin{array}{c}0.165^{* * *} \\
(9.79)\end{array}$ & $\begin{array}{c}0.074 * * * \\
(7.13)\end{array}$ & $\begin{array}{l}0.125 * * * \\
(7.40)\end{array}$ \\
\hline Number of observations & 995 & 1010 & 933 & 1892 & 2843 & 1121 \\
\hline
\end{tabular}

Source: Labor Force survey and Complementary survey on Working Conditions, 1998.

Note: ATT is the average effect of the treatment on the treated. Absolute values of t-statistics are in parentheses, with bootstrapped standard errors for the ATT (50 replications). Significance levels are respectively $1 \%(* * *), 5 \%(* *)$, and $10 \%(*)$. 
Table 6. Quantile decomposition of the log wage technological differential, by occupations

\begin{tabular}{|c|c|c|c|c|c|c|c|c|c|}
\hline \multirow[t]{2}{*}{ Decomposition } & \multicolumn{3}{|c|}{$\begin{array}{l}\text { Difference in characteristics } \\
\qquad \beta^{t}\left(x^{m}-x^{t}\right)\end{array}$} & \multicolumn{3}{|c|}{$\begin{array}{c}\text { Difference in coefficients } \\
x^{m}\left(\beta^{n}-\beta^{t}\right)\end{array}$} & \multicolumn{3}{|c|}{$\begin{array}{l}\text { Total difference } \\
\beta^{n} x^{m}-\beta^{t} x^{t}\end{array}$} \\
\hline & MOD1 & MOD2 & MOD3 & MOD1 & MOD2 & MOD3 & MOD1 & MOD2 & MOD3 \\
\hline \multicolumn{10}{|l|}{ Managers } \\
\hline Percentile 10 & 0.1122 & 0.1124 & 0.0748 & -0.1376 & -0.1296 & 0.0745 & -0.0254 & -0.0172 & 0.1493 \\
\hline Percentile 25 & 0.1285 & 0.1398 & 0.0426 & -0.0243 & -0.0532 & 0.0693 & 0.1042 & 0.0866 & 0.1119 \\
\hline Percentile 50 & 0.0029 & 0.0114 & 0.0697 & 0.0437 & 0.0309 & 0.0501 & 0.0466 & 0.0423 & 0.1198 \\
\hline Percentile 75 & -0.0018 & 0.0181 & 0.1070 & 0.0880 & 0.0505 & 0.0586 & 0.0863 & 0.0686 & 0.1656 \\
\hline Percentile 90 & 0.0098 & -0.0111 & 0.1212 & 0.2773 & 0.1388 & 0.0669 & 0.2871 & 0.1276 & 0.1882 \\
\hline Mean & 0.0362 & 0.0857 & 0.0531 & 0.0209 & 0.0530 & 0.0901 & 0.0571 & 0.1388 & 0.1433 \\
\hline \multicolumn{10}{|l|}{ Intermediate prof. } \\
\hline Percentile 10 & -0.0192 & 0.0194 & 0.0281 & 0.1055 & 0.1312 & 0.0946 & 0.0864 & 0.1506 & 0.1227 \\
\hline Percentile 25 & -0.0259 & -0.0052 & 0.0457 & 0.0850 & 0.1160 & 0.0513 & 0.0591 & 0.1108 & 0.0970 \\
\hline Percentile 50 & 0.0014 & 0.0258 & 0.0465 & 0.0550 & 0.0455 & 0.0118 & 0.0564 & 0.0713 & 0.0583 \\
\hline Percentile 75 & -0.0155 & 0.0339 & 0.0326 & 0.0929 & 0.0462 & 0.0509 & 0.0775 & 0.0802 & 0.0835 \\
\hline Percentile 90 & -0.0471 & -0.0306 & 0.0102 & 0.1010 & 0.1156 & 0.0035 & 0.0539 & 0.0849 & 0.0137 \\
\hline Mean & 0.0015 & 0.0259 & 0.0375 & 0.0717 & 0.0561 & 0.0361 & 0.0732 & 0.082 & 0.0737 \\
\hline \multicolumn{10}{|l|}{ Technicians } \\
\hline Percentile 10 & -0.0447 & 0.0041 & 0.0185 & 0.0841 & 0.0534 & 0.0119 & 0.0393 & 0.0574 & 0.0304 \\
\hline Percentile 25 & -0.003 & 0.0076 & 0.0296 & 0.0556 & 0.0520 & 0.0167 & 0.0525 & 0.0595 & 0.0463 \\
\hline Percentile 50 & 0.0239 & 0.0328 & 0.0286 & 0.0451 & 0.0226 & 0.0121 & 0.0690 & 0.0554 & 0.0407 \\
\hline Percentile 75 & 0.0121 & 0.0422 & 0.0422 & 0.0621 & 0.0593 & 0.0344 & 0.0742 & 0.1015 & 0.0766 \\
\hline Percentile 90 & 0.0060 & 0.0302 & 0.0387 & 0.0926 & 0.0731 & 0.0725 & 0.0986 & 0.1033 & 0.1112 \\
\hline Mean & 0.0157 & 0.0344 & 0.0388 & 0.0424 & 0.031 & 0.0217 & 0.0581 & 0.0654 & 0.0604 \\
\hline \multicolumn{10}{|l|}{ Employees } \\
\hline Percentile 10 & 0.1839 & 0.1756 & 0.1632 & 0.2414 & 0.1395 & 0.1216 & 0.4254 & 0.315 & 0.2847 \\
\hline Percentile 25 & 0.1766 & 0.1642 & 0.1475 & 0.1007 & 0.0764 & 0.0576 & 0.2773 & 0.2406 & 0.2050 \\
\hline Percentile 50 & 0.1208 & 0.1482 & 0.1376 & 0.1362 & 0.0482 & 0.0582 & 0.2570 & 0.1964 & 0.1958 \\
\hline Percentile 75 & 0.1378 & 0.1482 & 0.1471 & 0.0776 & 0.0258 & 0.0522 & 0.2154 & 0.1740 & 0.1992 \\
\hline Percentile 90 & 0.1482 & 0.1388 & 0.1205 & 0.0876 & 0.0358 & 0.0534 & 0.2358 & 0.1746 & 0.1739 \\
\hline Mean & 0.1643 & 0.1604 & 0.1503 & 0.1081 & 0.0624 & 0.0673 & 0.2724 & 0.2228 & 0.2176 \\
\hline \multicolumn{10}{|l|}{ Skilled prod. Workers } \\
\hline Percentile 10 & 0.0546 & 0.0637 & 0.0701 & 0.0431 & 0.0500 & 0.0624 & 0.0977 & 0.1137 & 0.1325 \\
\hline Percentile 25 & 0.0452 & 0.0517 & 0.0703 & 0.0641 & 0.0615 & 0.0595 & 0.1094 & 0.1132 & 0.1298 \\
\hline Percentile 50 & 0.0438 & 0.0625 & 0.0766 & 0.0696 & 0.0548 & 0.0691 & 0.1134 & 0.1173 & 0.1458 \\
\hline Percentile 75 & 0.0212 & 0.0450 & 0.0570 & 0.0923 & 0.0737 & 0.1031 & 0.1135 & 0.1187 & 0.1601 \\
\hline Percentile 90 & 0.0072 & 0.0423 & 0.0491 & 0.0965 & 0.0966 & 0.1012 & 0.1037 & 0.1389 & 0.1503 \\
\hline Mean & 0.0418 & 0.0516 & 0.0653 & 0.069 & 0.0677 & 0.0791 & 0.1108 & 0.1193 & 0.1444 \\
\hline \multicolumn{10}{|l|}{ Unskilled prod. Workers } \\
\hline Percentile 10 & 0.0673 & 0.0797 & 0.1199 & 0.2366 & 0.2047 & 0.3810 & 0.3038 & 0.2844 & 0.5009 \\
\hline Percentile 25 & 0.0956 & 0.0485 & 0.0719 & 0.1195 & 0.1754 & 0.1742 & 0.2150 & 0.2239 & 0.2461 \\
\hline Percentile 50 & 0.0575 & 0.0465 & 0.0602 & 0.0679 & 0.1078 & 0.1241 & 0.1253 & 0.1543 & 0.1843 \\
\hline Percentile 75 & 0.0600 & 0.0555 & 0.0760 & 0.0857 & 0.0424 & -0.0031 & 0.1457 & 0.0979 & 0.0730 \\
\hline Percentile 90 & 0.0524 & 0.0654 & 0.0388 & 0.0849 & 0.0405 & -0.0639 & 0.1373 & 0.1059 & -0.0250 \\
\hline Mean & 0.0813 & 0.0596 & 0.0707 & 0.0944 & 0.0912 & 0.1264 & 0.1757 & 0.1507 & 0.1971 \\
\hline
\end{tabular}

Source: Labor Force survey and Complementary survey on Working Conditions, 1998.

Note: MOD1 stands for at least one ICT, MOD2 for at least 2 ICT, and MOD3 for at least 3 ICT. 
Figure 1. Observed technological premium

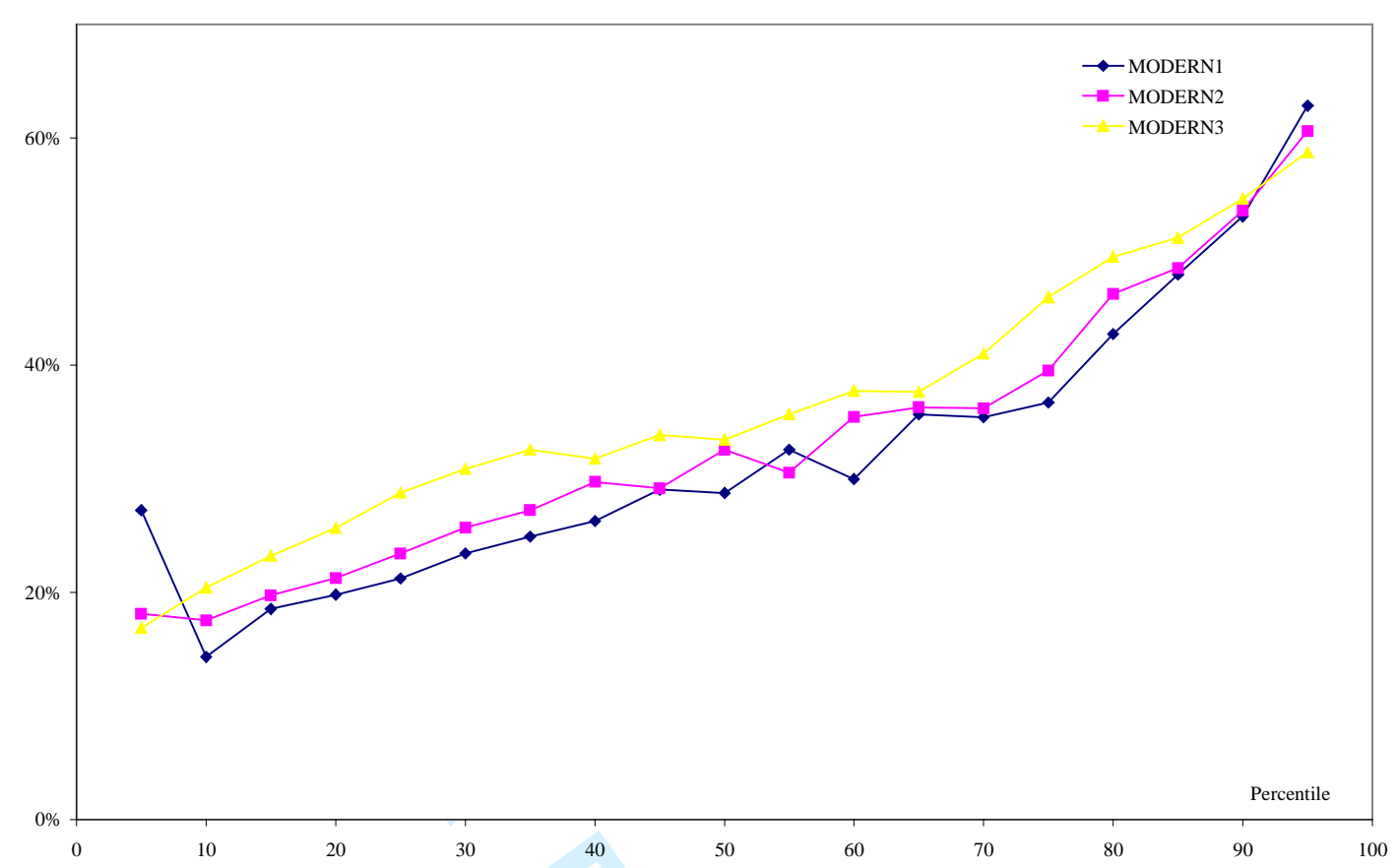

Source: Labor Force survey and Complementary survey on Working Conditions, 1998.

Note: MODERN1 stands for at least one ICT, MODERN2 for at least 2 ICTs, and MODERN 3 for at least 3 ICTs.

Figure 2. Technological diffusion among occupations

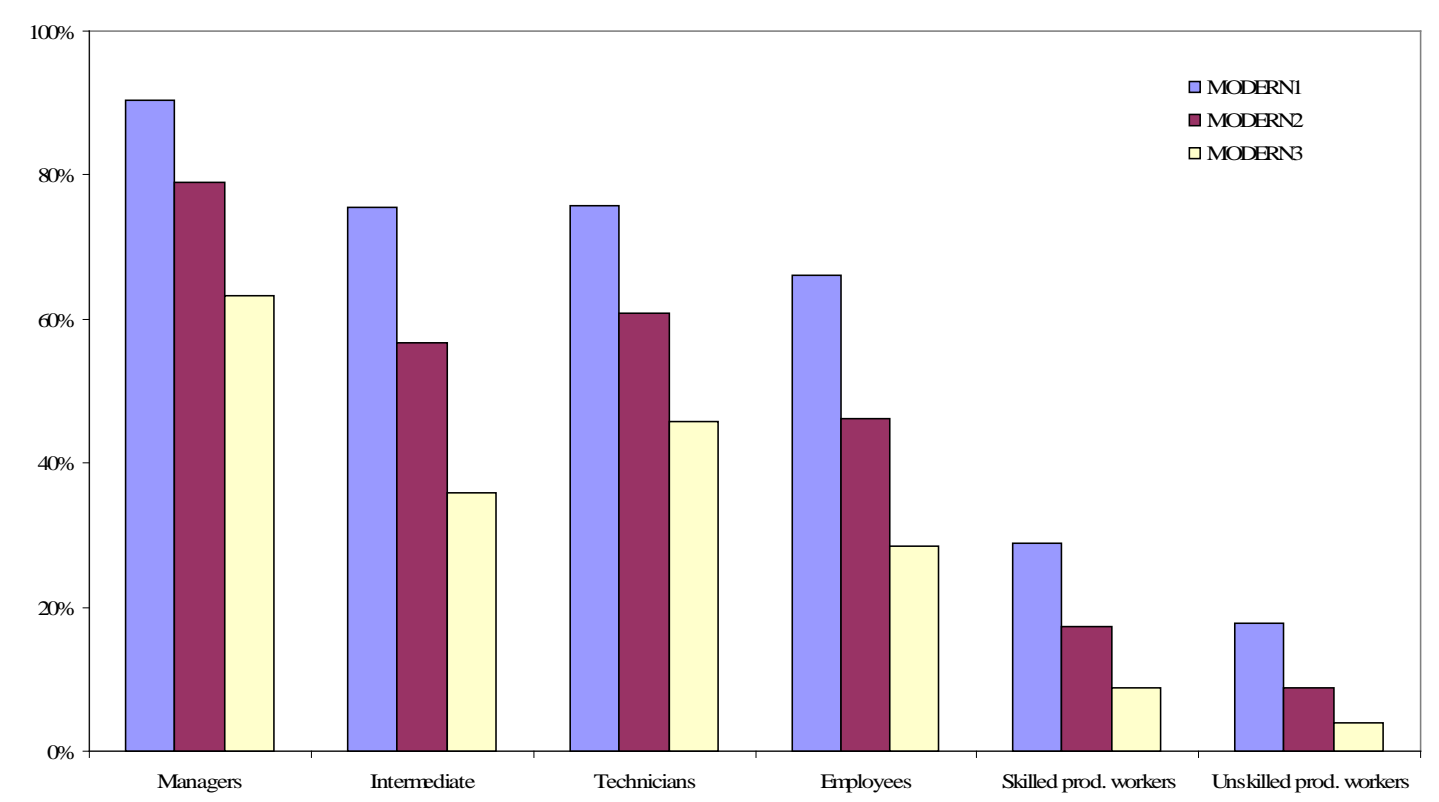

Source: Labor Force survey and Complementary survey on Working Conditions, 1998.

Note: MODERN1 stands for at least one ICT, MODERN2 for at least 2 ICT, and MODERN 3 for at least 3 ICT. 


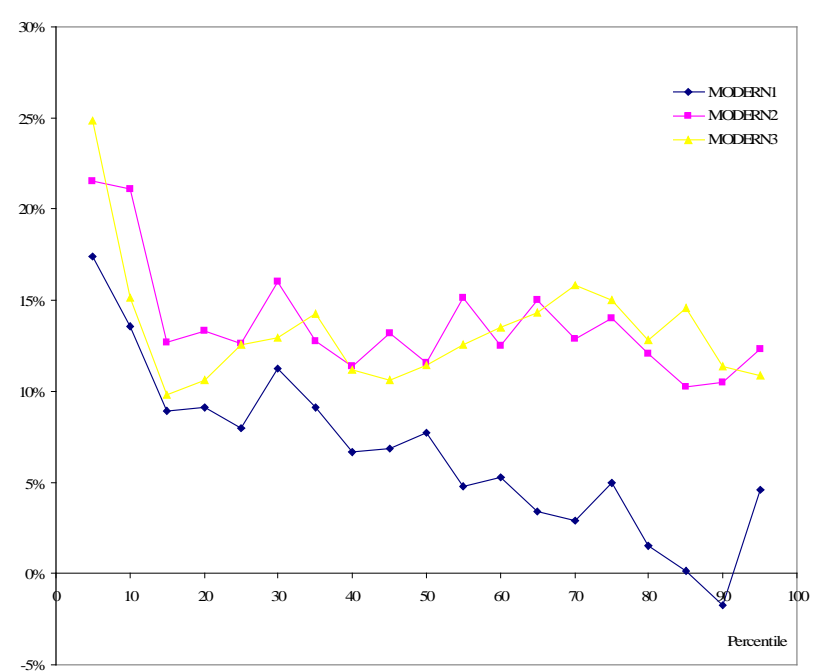

B. Intermediate profession

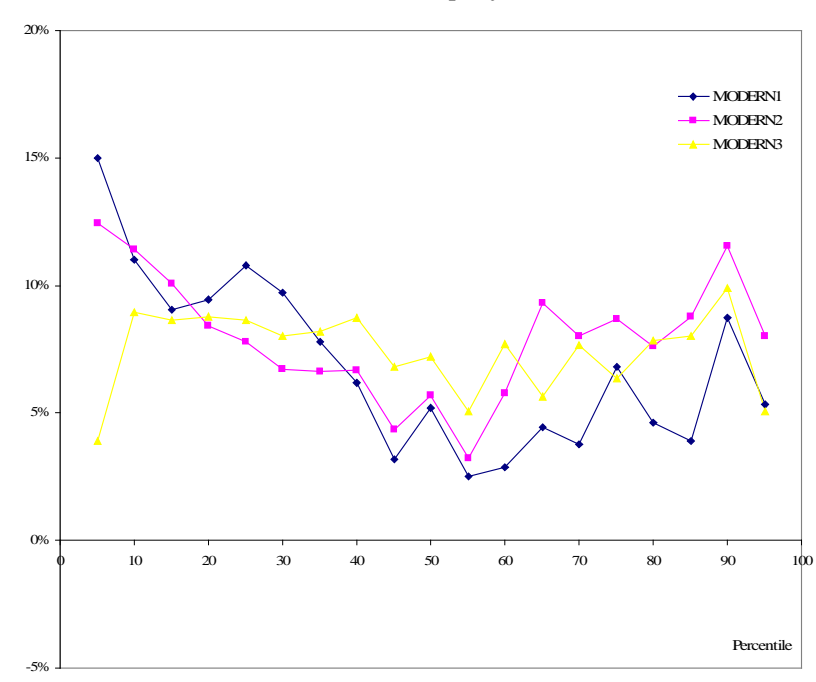

A. Managers

Figure 3. Observed technological premium by occupations C. Technicians

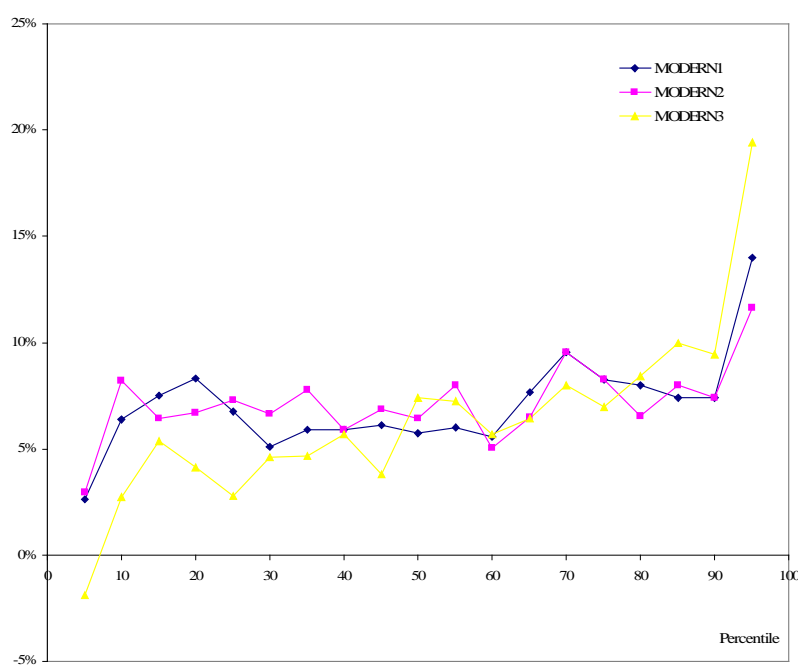

D. Employees

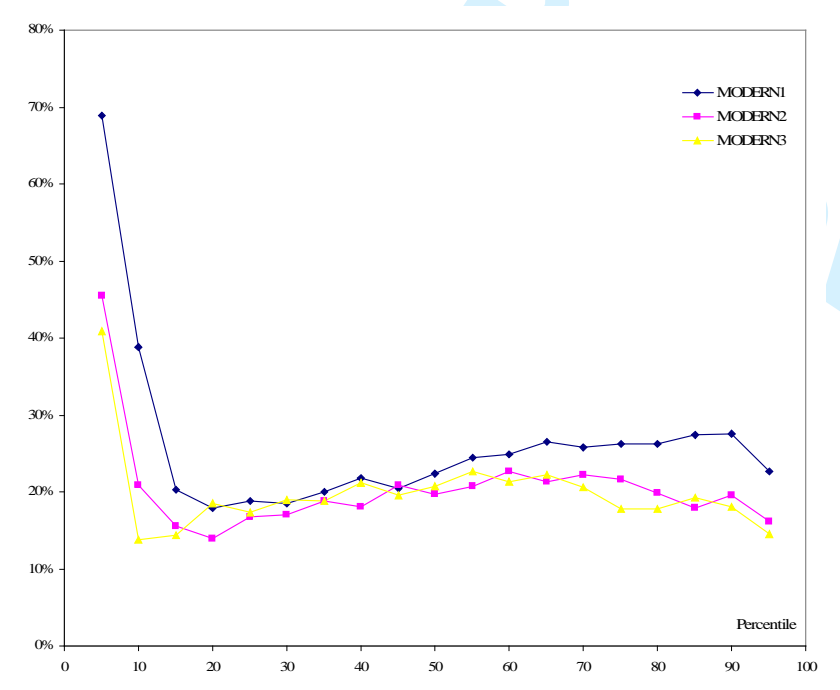

Source: Labor Force survey and Complementary survey on Working Conditions, 1998.

Note: MODERN1 stands for at least one ICT, MODERN2 for at least 2 ICT, and MODERN 3 for at least 3 ICT.
E. Skilled production workers
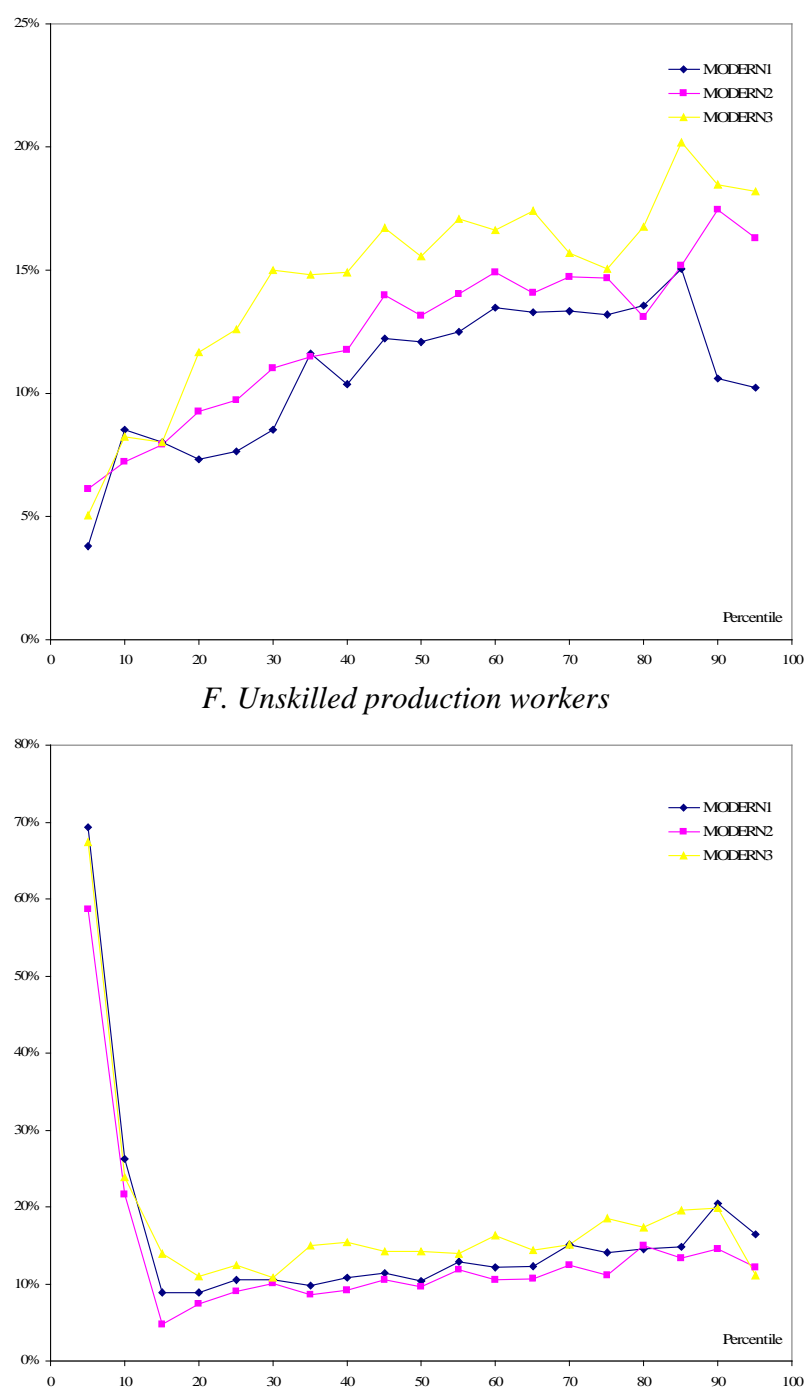

Editorial Office, Dept of Economics, Warwick University, Coventry CV4 7AL, UK 
Figure 4. Estimated technological premium

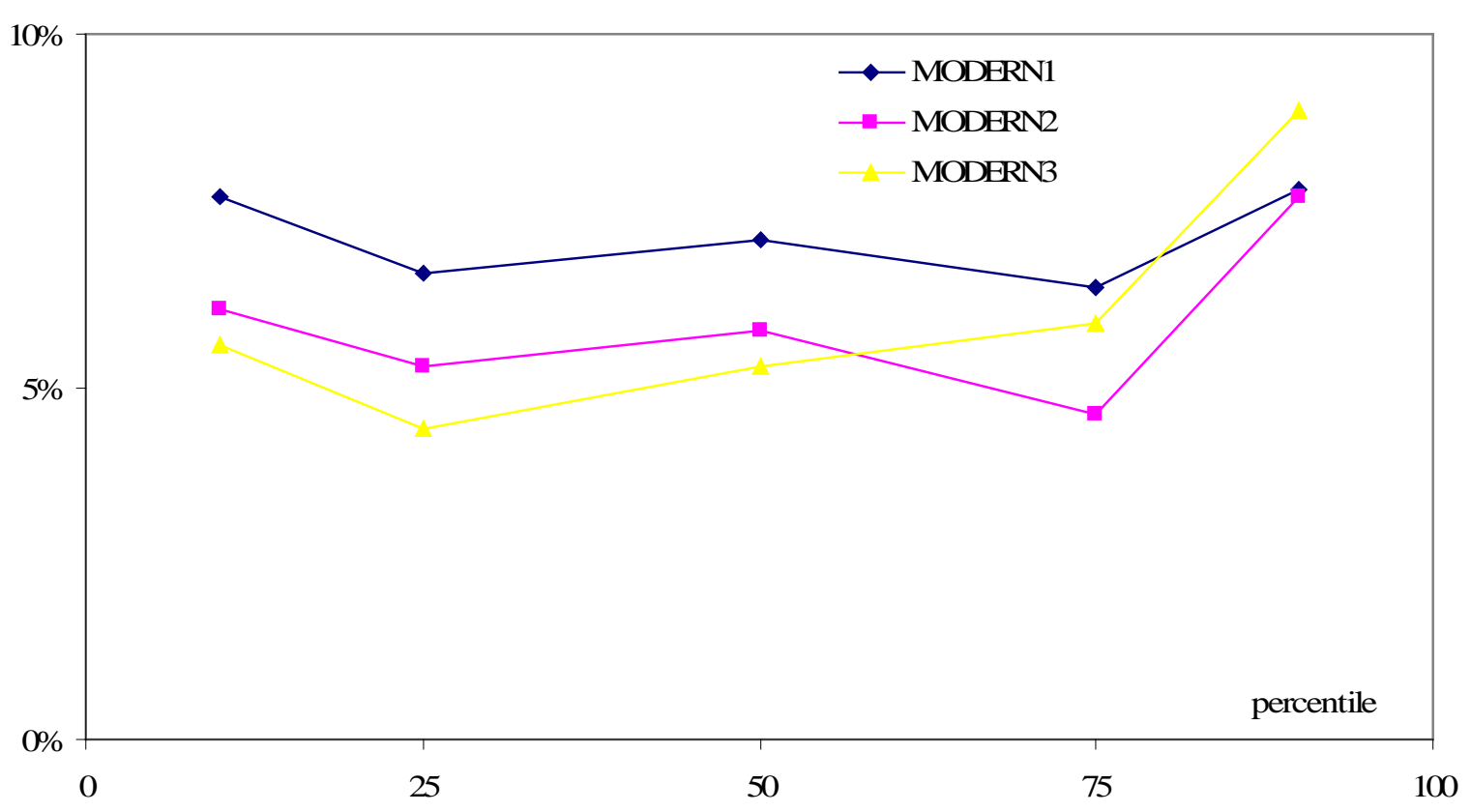

Source: Labor Force survey and Complementary survey on Working Conditions, 1998.

Note: MODERN1 stands for at least one ICT, MODERN2 for at least 2 ICT, and MODERN 3 for at least 3 ICT. 